\title{
The conceptualisation of cognitive tools in learning and technology: A review
}

\author{
Azar Pakdaman-Savoji \\ Islamic Azad University, Saveh Branch; Visiting scholar at Simon Fraser University \\ John Cale Nesbit \\ Faculty of Education, Simon Fraser University \\ Natalia Gajdamaschko \\ Faculty of Education, Simon Fraser University
}

\begin{abstract}
The term cognitive tool has been used in many areas of academic specialisation, where it has taken on multiple connotations. In this historical and systematic review, we investigate the conceptualisation of cognitive tools in the learning sciences and educational technology. First, the theory of cognitive tools vis-à-vis learning and development is traced from Vygotsky and Soviet psychology through to its use in current educational technology and learning design. Second, we present a systematic review of cognitive tools in peer-reviewed research literature. We found the term cognitive tool was often used vaguely or with extreme generality. When used more specifically, it referred to communication methods such as visualisations, metaphors, symbols, and hypermedia; or interactive interfaces and environments such as templates, databases, simulations, games, and collaborative media. We offer a definition of software-based cognitive tools founded on the attributes of representation, interactivity, and distributed cognition, which commonly feature in the work of influential theorists; and we explain implications of the definition for designing, evaluating, and researching learning technologies.
\end{abstract}

The term cognitive tool has seen extensive usage in a range of education-related academic disciplines. Theorists or researchers taking up the term often gave it a sense that differed, sometimes radically, from the way it was used by prior writers. Throughout its history as an intellectual port of call, the notion of cognitive tool has been linked with cognitive development (Vygotsky, 1930/1999), computer technologies (Pea, 1985), distributed cognition (Salomon, 1993), constructivism (Jonassen, 1995), scaffolded cognitive processing, knowledge visualisation, metaphor, and a host of other ideas detailed in this article. The various interpretations seem so diverse, and are sometimes presented with such little reference to prior work, we believe there is a need for an inquiry into the origins of the concept, how it has evolved to inhabit specialised intellectual niches, and whether its divergent meanings retain a common or core sense that offers value in the field of educational technology and learning design.

In this review, we examine the theory of cognitive tools and its implications for designing learning technologies. First, we historically trace the main themes of the concept from its roots in the Soviet psychology of Vygotsky and his associates through to its widespread use in the learning sciences and the study of educational technology. Second, we report a systematic review of peer-reviewed journal articles that recorded and categorised uses of the term cognitive tool. Finally, we consider what ideas lie at the core of the various conceptualisations of cognitive tools, judge which of these ideas have a continuing role to play in the learning sciences, and describe their implications for designing learning technologies.

\section{Cognitive tools in the history of psychology and learning design origins in Soviet psychology}

Vygotsky's approach to human psychology, developed in the context of an early twentieth century science he found to be in crisis, introduced many new and important concepts. A central idea of his new psychological theory was a focus on the existence of internal and external tools that transform the structure of mental functioning (Cole \& Gajdamaschko, 2007; Gajdamaschko, 2015). Without these tools, Vygotsky insisted, we can't bridge the gap between genetically inherited, mainly reactive functions and complex, cultural functions. Cultural functions, or as Vygotsky called them, higher psychological functions, are 
mediated by tools, and the inclusion of tools into their structure allows us to explain the crucial role of culture and history in psychological development (Gajdamaschko, 2015).

Vygotsky's focus on mediation, the central notion of his views of learning and development, represents a departure from other psychological and educational theories. He argued that the inclusion of cultural tools in the process of psychological growth can alter the trajectory or pattern of development, enabling a learner to solve much more sophisticated problems and empowering her with the wisdom of previous generations via the meaning of the tool (Vygotsky, 1930/1997). External and internal tools are instruments that learners use to modify and regulate their behaviour, and the analysis of these tools is an essential element of Vygotsky's approach to understanding human development. In the developmental process, Vygotsky explains, pre-existing mental processes are joined and transformed by culturally designed tools that are internalised through social interaction. The resulting higher psychological functions are viewed by Vygotsky as self-regulated processes that are cultural, historical, and social in their origin. Just as the introduction of a new type of machine into a workplace can lead to a radical reorganisation of work and division of labour, internalisation of psychological tools into mental functioning can radically reshape learners' thinking.

Vygotsky's (1978) claim contrasts sharply with psychological theories, especially Piagetian theory, which focuses on the developing child as an individual agent. For Vygotsky, culture, via the mediation of tools, is fundamentally integrated within a person's mental function and does not merely facilitate or overlie their natural development. As Wertsch (1998) put it, to understand the role of culture and society in human development we must study "the irreducible tension between agent and mediational means" (p. 25), where the tools empower but simultaneously impose their own constraints on the mental functioning of the learner.

Current conceptualisations of cognitive tools in the field of learning technologies are rooted in, but different from, the Vygotskian theory of cognitive tools. For Vygotsky, cognitive tools are omnipresent and inevitable means by which thinking is shaped by culture, and the question is not whether the use of cognitive tools is desirable but rather whether the cognitive tools being internalised by learners are the most suitable for promoting their cognitive development. For several decades, Vygotskian educational researchers have evaluated and redesigned the cognitive tools used in Russian schools and in so doing have significantly shaped the Russian curricula. For example, Davydov and Tsvetkovich (1991) noted the problem inherent in having children develop the concept of number as a by-product of counting operations, as is usually the case in traditional mathematics classrooms. In Vygotskian terms, counting is a cognitive tool (Schmittau, 2003). When children identify numbers by counting, they interpret them only as positive integers, and this persistent misconception hinders their later understanding of fractions and irrational numbers. In Davydov and Tsvetkovich's curriculum, which has been established in Russia for many years, the concept of number is grounded in the operation of measurement rather than the operation of counting. Furthermore, in their curriculum, children progress from comparing the length (or other dimension) of nearby objects to comparing things that can't be physically aligned next to each other using a portable, intermediate object (e.g., an eraser), and finally to measuring objects using any smaller object as the unit of measurement. A measurement is expressed as the ratio of the length of an object to the length of measurement unit. Grounding the concept of number in the cognitive tool of measurement allows for the possibility, in later grades, of a fraction instead of a whole number emerging as the measured quantity. Crucially, this means the later introduction of multiplication, fractions and irrational numbers does not require learners to reconceptualise the meaning of number. This example shows how having learners internalise a different or redesigned cognitive tool can alter how easily they, years later, acquire more advanced concepts.

\section{Technologies and designs for learning}

Before 1985, American theorists described the use of software tools as amplifying learners' abilities in terms that showed no influence from Vygotskian theory. Taylor (1980) saw the educational value of software tools (e.g., calculators) lying only in their capacity to aid completion of requisite but secondary tasks. They might "teach the user something during use, but any such teaching is most likely accidental and not the result of any design to teach" (p. 8). Pea (1985), however, advocated shifting the conceptualisation of learning technologies from the metaphor of cognitive amplification to one of cognitive reorganisation. He argued the metaphor of amplification describes gains in the efficiency of existing cognitive processes, but that cognitive tools have the potential to change how cognition is organised. Citing Vygotsky (1962) and his colleague Luria (1976), Pea connected the tool-like function of symbols in Vygotsky's 
understanding of cognitive activity and the role of the computer as a symbol manipulator. Unlike amplification, reorganisation implies qualitative changes in how learners perceive and operate on their world. The technologies that Pea saw as capable of promoting cognitive reorganisation included programmable tools such as electronic spreadsheets and interactive programming environments, and also software that for the purposes of this article we call digital learning environments. Digital learning environments simulate learnable features of the world or dynamically represent abstract ideas and relationships. Digital learning environments include microworlds for engaging with Newtonian mechanics (DiSessa, 1983), geometry (Scher, 2000), and medical diagnostics (Lajoie, Lavigne, Guerrera, \& Munsie, 2001); and intelligent tutoring systems (ITSs) that offer an interface in which students can choose which operations to apply in performing each step of solving a problem (Anderson, Corbett, Koedinger, \& Pelletier, 1995). Kozma (1987) described how cognitive tools present models that can be internalised, as when a student develops the ability to think structurally about an essay through working with the outline function in a word processor.

Building on Pea's (1985) ideas, Salomon, Perkins, and Globerson (1991) distinguished between "tools that work for us" and "tools with which we work" (p. 3). Whereas the former are devices that afford little direct interaction (e.g., a communications satellite), the latter are cognitive tools we partner with to accomplish tasks (e.g., an electronic spreadsheet). Examining how students work with cognitive tools or "technologies of the mind" (p. 4), Salomon et al. echoed Pea's contrast between the metaphors of amplification and reorganisation - they differentiated the "effects with" the tools, which are varieties of enhanced performance, and the potential "effects of" the tools, which are transferable, long term changes in students' abilities. They argued that desired educative effects of cognitive tools cannot be expected automatically but must be designed into the tools and the contexts in which they are used. Salomon (1993) observed that computer-based tools can take on much of the cognitive effort required by a task and thereby offer their users an intellectual partnership. He noted the Vygotskian character of this exchange and how, when used for pedagogical purposes, the operations shared by distributed cognition often become internalised by the learner.

Drawing on Piagetian learning theory, Duchastel (1990) distinguished two kinds of cognitive tools for learning. "Power tools" (p. 4) are environments in which learners might solve problems, create art, or write computer programs, perhaps with guidance from the system. He saw power tools as provoking Piagetian accommodation via schema restructuring and resolution of fundamental misconceptions. "Assimilatory tools" (p. 4) augment learners' ability to adapt new information to fit into existing schemas. Duchastel regarded encyclopedias, textbooks, and hypermedia as examples of assimilatory tools.

\section{Tools for constructivist learning}

The essence of constructivism is the belief, advocated by Piaget and now widely accepted by many psychologists and educational theorists, that humans actively build much or all of what they know and act as decision-making agents in doing so (Moshman, 1982; Von Glaserfeld, 1989). During the 1990s, as the constructivist principle gained currency in the field of learning technologies, computer-based cognitive tools were often portrayed as key components of learning environments in which learners could operate as they engaged with a subject as autonomous agents (Dalgarno, 2001).

Jonassen and his colleagues wrote extensively about computer-based cognitive tools, sometimes calling them "mindtools", and argued for their significance in constructivist learning (Jonassen, 1995, 1996, 2000; Jonassen \& Carr, 2000; Jonassen, Carr, \& Yueh, 1998; Jonassen \& Reeves, 1996). Cognitive tools are defined as knowledge representation tools that can "enhance the power of human beings during thinking, problem solving, and learning" (Jonassen \& Reeves, 1996, p. 693), "activate cognitive and metacognitive learning strategies" (Jonassen, 1992, p. 2), and "function as intellectual partners with the learner in order to engage and facilitate critical thinking and higher-order learning', (Jonassen, 1996, p. 9). While Salomon (1993) saw computer-based cognitive tools as scaffolds whose benefits lay in the cognitive effects remaining after the tools have been removed, Jonassen and Reeves argued that performance with a tool can be a goal in itself because technologies are an inevitable and ongoing component of contemporary contexts. They believed cognitive tools had the potential to open a path to constructivist learning and transferable knowledge in educational systems dominated by routinised practice and reproduction of given information. Jonassen (2000) described how students' intentional engagement with cognitive tools promotes meaningful learning and reflective thinking. 
Noting that each type of computer-based cognitive tool uses a particular formalism to organise information, Jonassen and his colleagues argued that the availability of many types of these tools, from spreadsheets to hypermedia, affords opportunities for multiple representation of knowledge (Jonassen \& Carr, 2000; Jonassen et al., 1998). They claimed students would reap far greater benefit from designing and building new artefacts with the tools rather than interacting with them as users or consumers. Students who work with and internalise multiple representations were theorised to have a deeper and more flexible understanding of a topic that would transfer more naturally to real-life situations. Jonassen and his colleagues categorised databases and concept mapping software as semantic organisation tools because both implement formalisms for explicitly representing relationships between objects or concepts. Spreadsheets, system modelling software, expert systems, and programmable environments were grouped together as dynamic modelling tools because they allow students to build models so they can ask "what if" questions whose answers depend on hypothetical or variable conditions. Software that can generate images of abstract or normally invisible phenomena, like molecular structures, were counted as visualisation tools. Hypermedia publishing tools, perhaps best exemplified today by Wikipedia, were categorised as knowledge construction tools. Finally, online conferencing software, computer-supported collaborative argumentation systems, and the like were categorised as socially shared cognitive tools. Jonassen (2011) emphasised that tools supplied in a learning environment should be selected according the types of thinking that require scaffolding. He observed, for example, that solving design problems requires construction of mental models, a process that can be scaffolded by the use of modelling software. Much of the research over the last decade reporting on diverse cognitive tools continued to cite the taxonomy developed by Jonassen and Carr (2000) and Jonassen et al. (1998). Among these, Collins and Knoetze (2014) described how undergraduates can develop procedural and conceptual knowledge by working with an expert system shell on discovery learning tasks, and Herrington and Parker (2013) studied the use of web-based tools for authentic learning in first-year teacher education.

Whereas Vygotsky (1978) emphasised the interaction between the learner and teacher (or more knowledgeable other) and saw the cognitive tool as mediating this key interaction, Pea (1985), Salomon (1993), and Jonassen (1992) foregrounded interactions between the learner and the cognitive tool. Jonassen and Reeves (1996) claimed that cognitive tools should be "learner-controlled not teacher-controlled" because they fail when used for "traditional academic tasks set by teachers" (p. 697). They admitted that teachers have a guiding role as long as the problems to which cognitive tools are applied originate with learners. This is a far cry from the Vygotskian understanding that cognitive tools constrain as well as empower the endogenous predispositions of learners (Wertsch, 1998).

Jonassen and Reeves (1996) argued against the use of computer-based ITSs because they saw such systems as only mimicking the traditional controlling role of teachers. In the introductory chapter to their book Computers as Cognitive Tools, Derry and Lajoie (1993) outlined a fundamental division then existing in the field of learning technology between the model builders designing ITSs that incorporate student models (Koedinger \& Anderson, 1993) and non-modelers like Salomon (1993) and Jonassen (1992).

B. Kim and Reeves (2007) noted this same lack of consensus in the conceptualisation of cognitive tools and observed that as the term became widely used in the field of learning technologies it lost its original grounding in psychological theory. As justification of the earlier categorisation by Jonassen and Carr (2000) and Jonassen et al. (1998), they proposed only software programs that contribute a middle level of executive control qualify as cognitive tools. Programming languages were excluded because they are too passive, and ITSs because they take on too much control. Kim and Reeves considered databases, concept mapping tools, simulation tools, and microworlds to be cognitive tools because they contribute expertise that shapes the nature of the activity and at the same time leave much of the higher-order decision-making to the learner.

Student-centred learning theorists Iiyoshi, Hannafin, and Wang (2005) conceptualised cognitive tools as instrumental in reducing the cognitive load associated with open learning environments and as essential catalysts for learning in complex environments. M. C. Kim (2012) reviewed the theoretical foundations of software-based cognitive tools and presented a conceptualisation emphasising social construction of scientific knowledge in collaborative learning environments. More than earlier constructivist theorists, Kim's social-constructivist conceptualisation recognised the importance of instructors' roles in selecting problems and projects, focusing students' attention, diagnosing student difficulties, providing just-in-time assistance, mediating student collaborations, and providing formative feedback. 
Metacognition and self-regulated learning

Computer-based cognitive tools can be used to scaffold learners' monitoring and control of their cognitive processes as they solve problems and work towards learning goals. Metacognition is the awareness of one's own thinking and capacity for strategic action, and self-regulated learning is the use of that understanding to self-direct knowledge construction (Dinsmore, Alexander, \& Loughlin, 2008). Cognitive tools can be designed to make metacognition more explicit, and thereby expand learners' capacity for agentic control. Lajoie (1993) described metacognitive support functions that cognitive tools can offer students engaged in problem-solving. Learning to solve ill-structured problems such as diagnosing diseases in BioWorld (a hospital simulation that provides a realistic environment for students to learn about diseases through solving specific patient cases, Lajoie et al., 2001) can involve extended explorations of a large and complex problem space. An essential function of cognitive tools in such problem-solving environments is supporting the evaluation of competing hypotheses. To that end, BioWorld provided an argumentation palette that allowed students to manage their hypotheses and a belief meter that they could use to record their level of confidence in each hypothesis. Re-presenting past actions and judgements to the learner via cognitive tools in problemsolving environments such as BioWorld was hypothesised to model and promote internalisation of expert metacognitive processes (Lajoie, 1993).

\section{A survey of cognitive tools in peer-reviewed research}

We conducted a systematic survey of references to cognitive tools in articles published in peer-reviewed journals up to and including 2018. The purpose of the survey was to examine quantitatively how the concept of cognitive tools has been used in research and theory relating to learning and instruction. This review addressed the following questions:

- How have references to cognitive tools changed over time?

- What types of cognitive tools are being described and empirically investigated?

- Which areas of scholarship in the learning sciences are making frequent references to cognitive tools?

- In empirical research relating to cognitive tools, which levels of schooling and subjects have been studied?

\section{Method}

A multiphase procedure, shown in Figure 1, was used for searching and coding published articles. The phases of the procedure were (a) systematic searching of electronic databases, (b) screening to exclude documents that did not meet eligibility criteria, and (c) structured coding of eligible articles.

To identify potentially relevant studies, a systematic electronic search was performed on three electronic databases (ERIC, PsycINFO, and Web of Science) selected for their coverage of research in education, psychology and the social sciences respectively. These were searched using the keyword "cognitive tool*" with search parameters set to capture peer-reviewed publications. The search was conducted in two stages. The first stage was conducted in March and April of 2016 and returned 1044 records. The second stage, covering 2016 to 2018, was conducted in 31 December 2018 and returned 101 records. A total of 1145 records were identified in these searches (ERIC, 235; PsycINFO, 396; Web of Science, 514). 


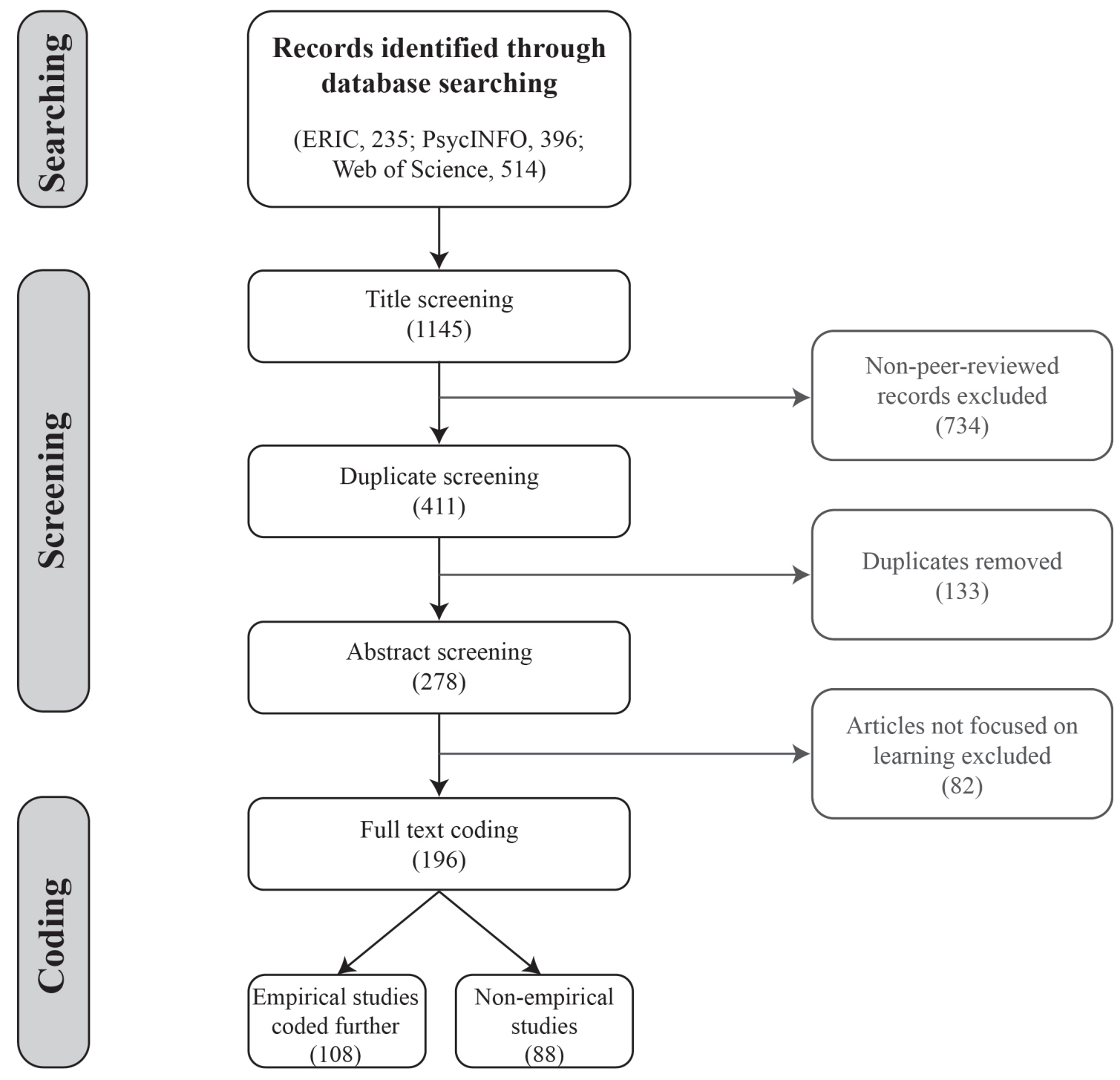

Figure 1. Multiphase procedure for searching, screening and coding articles

\section{Screening}

Titles and metadata were examined to exclude all but peer-reviewed journal articles. We also excluded articles not written in English and articles unrelated to learning in which the term cognitive tool referred to a cognitive assessment instrument. A total of 734 records were excluded and 411 peer-reviewed articles were imported to the Mendeley reference management software. Using Mendeley, 133 duplicates were removed, and the remaining 278 peer-reviewed articles were retained. In the abstract screening step, 82 articles were excluded because the cognitive tools they identified were not intended to promote learning of identified concepts, skills, interests, or motivations, and 196 peer-reviewed articles were eligible for further analysis.

\section{Coding}

Articles were coded for 7 variables: year of publication, number of references to the term cognitive tool, academic specialisation, type of cognitive tool, type of study (empirical vs. non-empirical), and for empirical studies, level of schooling and subject area. Some variables could be objectively coded by one of the researchers and required no reliability checking. For more subjective variables with predetermined codes, two researchers coded 20 randomly selected articles and obtained an average inter-rater agreement (Kappa) of $\kappa=.82$. After discrepancies in coding were discussed and resolved, one researcher coded the remaining articles. For variables which required the iterative development of codes, two researchers 
reviewed and discussed each article to obtain full agreement. The articles were coded as empirical if they reported gathering qualitative or quantitative data regarding a cognitive tool.

\section{Results}

We found 196 peer-reviewed journal articles that referred to learning with cognitive tools (see Appendix for references). Figure 2 shows the frequency of these in the 37 years from 1982 to 2018 . Very few articles (5\%) referred to cognitive tools before 1998, and 75\% appeared after 2004. A total of $116(59.2 \%)$ referred to cognitive tools as technologies such as specific software applications or information and communications technology (ICT) in general, while the remaining $80(40.8 \%)$ used the term to refer to non-technological tools, such as language, symbols, schemas, or metaphors. In the years 2005 to 2009, however, there was a marked increase (to 74\%) in the proportion of articles referring to technological cognitive tools. The figure indicates usage of the term declined somewhat in recent years yet retains considerable currency.

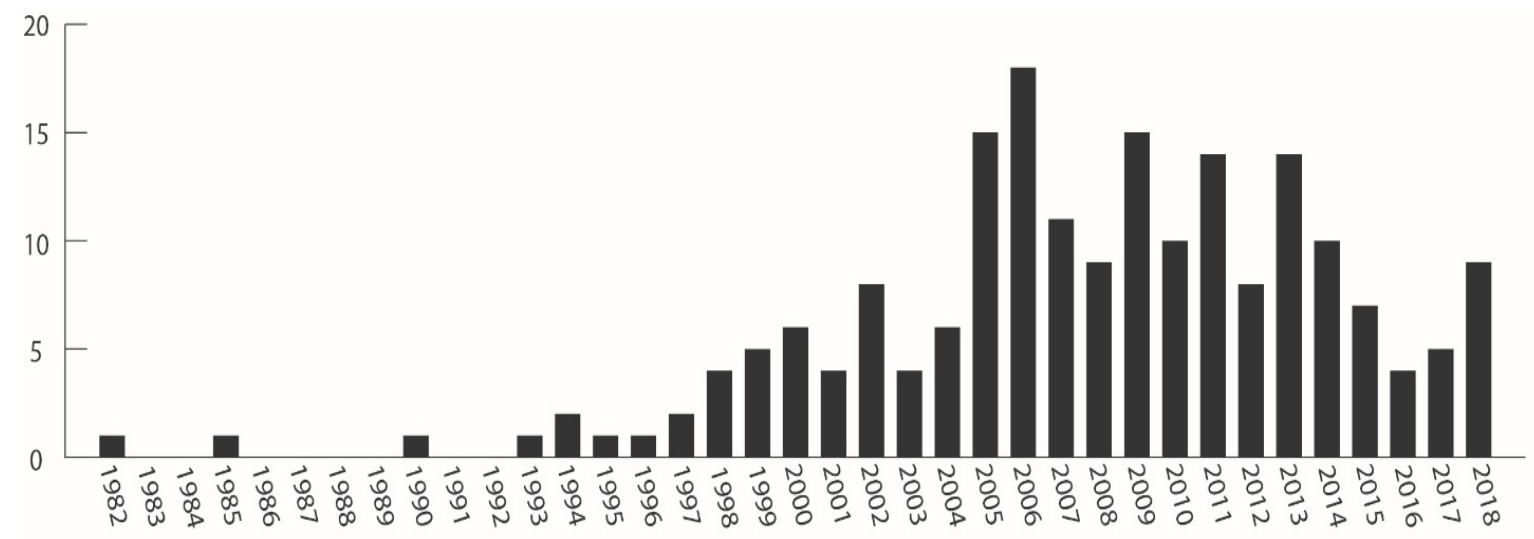

Figure 2. Distribution over time of articles referring to the use of cognitive tools for learning

Table 1 shows the distribution of frequencies with which the articles referred to cognitive tools. Notably, out of 196 articles, 29 referred to cognitive tools only once, and 29 only twice. We found most of the articles provided no definition of the term and no explanation for why it was used. For instance, in an article titled "Strategy Instruction from a Sociocognitive Perspective", Lenski and Nierstheimer (2002) used the term only once, in the abstract, to refer to reading and writing strategies. They gave no justification for identifying the strategies as cognitive tools and gave no indication as to which conceptualisation of cognitive tools they were referring to. Articles that made more references to the term were more likely to provide definitions and explanations for using it.

Table 1

Distribution of the frequency with which articles referred to cognitive tools

\begin{tabular}{lll}
\hline Frequency of references to cognitive tools & Articles & Cumulative percentage \\
\hline 1 time & 29 & 14.8 \\
2 times & 29 & 29.6 \\
3 to 10 times & 79 & 69.9 \\
More than 10 times & 59 & 100 \\
\hline
\end{tabular}

Table 2 shows the term cognitive tool was used mostly in areas of academic specialisation relating to education. In the table, "education" refers to educational specializations other than educational technology and educational psychology; and "other" refers to miscellaneous specialisations such as computer science, philosophy, and medicine. We observed that across the areas of academic specialisation, the concept of cognitive tool was used for widely varying purposes. For example, in sports psychology, it was used by Schack (2004), citing Vygotsky (1978), to emphasise the symbolic character of "basic action concepts" that constitute complex movements. Working in linguistics, Chen, $\mathrm{Li}, \mathrm{Li}$, Wang, and $\mathrm{Wu}$ (2013) referred to bilingualism as a cognitive tool that affects the phonological awareness of children; while Bender and Beller (2012) developed a psychological hypothesis that finger counting is a culturally encoded and embodied cognitive tool. 
Table 2

Academic specialisation of 181 articles referring to cognitive tools

\begin{tabular}{lll}
\hline Academic specialisation & Articles & Percentage \\
\hline Education & 71 & 36.2 \\
Educational technology & 57 & 29.1 \\
Educational psychology & 30 & 15.3 \\
Psychology & 20 & 10.2 \\
Linguistics & 6 & 3.1 \\
Other & 11 & 6.1 \\
\hline
\end{tabular}

We have already noted how theorists have used the term cognitive tools to refer to a wide variety of concepts and software, and our systematic review found evidence for this variety across the research literature. Figure 3 shows the frequency distribution for the types we coded. Our categorisation scheme was adapted from the five categories identified by Jonassen et al. (1998) which we added to, modified, and renamed to accommodate the references to cognitive tools we encountered.

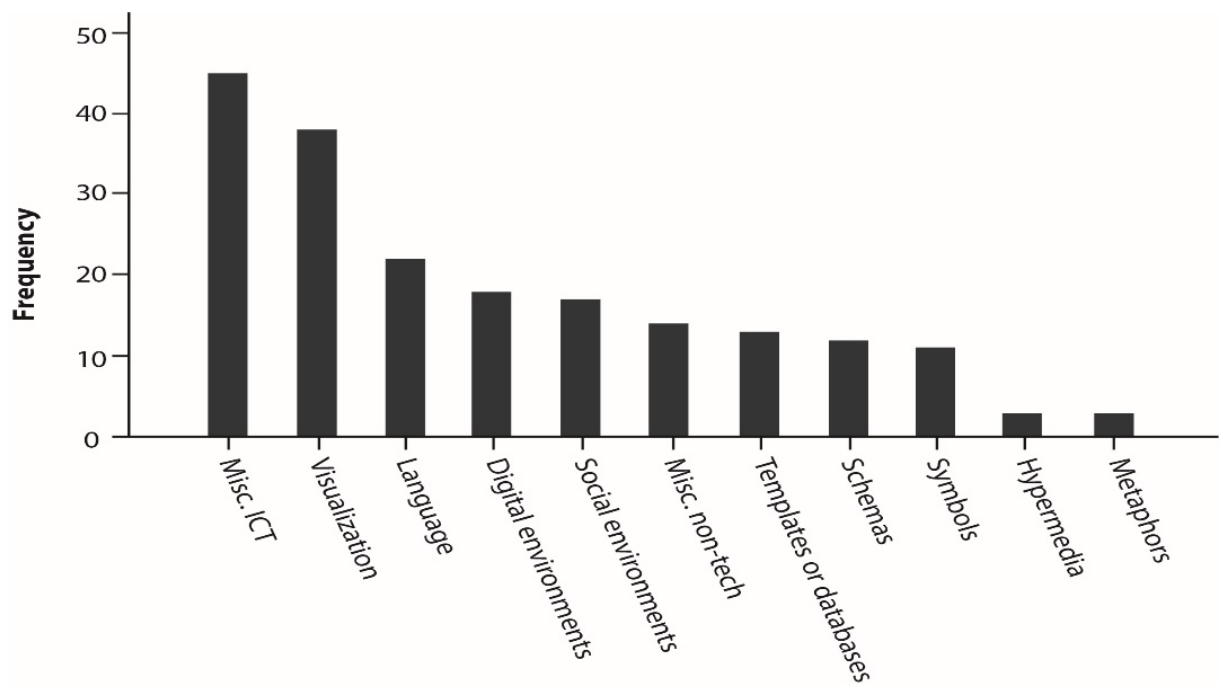

Figure 3. Articles categorised by the type of cognitive tool on which they focused

The template or database category included tools that enabled learners to organise information and identify the relationship between items ( $\mathrm{Li} \& \mathrm{Liu}, 2007$ ). The visualisation category included concept maps and Vee diagrams (Afamasaga-fuata'i, 2008), Geometer's Sketchpad (Contreras, 2011), computer-based animations to facilitate learning geography (Edsall \& Wentz, 2007), and other types of visualisations. The digital environments category included references to specific simulations (e.g., Hung, 2008); microworlds (e.g., Poitras, Lajoie, \& Hong, 2012) and computer games (e.g., Martinovic, Burgess, Pomerleau, \& Marin, 2015). The social environments category included specific references to educational media that facilitated communication among learners, such as online discussion forums (Stahl, 2006) and argument-sharing tools (e.g., Tambouris, Zotou, \& Tarabanis, 2014). The language category covered references to nontechnological tools denoting word knowledge (Mirolli, \& Parisi, 2009); language acquisition (De la Colina $\&$ Mayo, 2009), and so on. The schema category covered articles referring to either the general concept of schema (e.g., Arievitch, \& Stetsenko, 2000) or instances of schemas such as mental models of acids for chemistry students (e.g., McClary \& Talanquer, 2011). As shown in Figure 3, categories appearing less frequently were symbols (e.g., Miller, 2000), hypermedia (Yildirim, 2005), and metaphors (Zheng, 2015).

Two miscellaneous categories were created to account for references to tools that could not be readily classified or were extremely general. The miscellaneous ICT category was used for all general references to ICT. The miscellaneous non-technology category covered a wide variety of concepts or operations that authors claimed to be cognitive tools, such as inductive generalisation when used by children to make sense of their environment (Puche-Navarro \& Rodriguez-Burgos, 2015) and pedagogical literacy when used by teachers to develop how they reason about their professional practice (Maclellan, 2008). 
There were 108 empirical studies, and the other 88 articles were non-empirical reviews or theoretical analyses. The empirical studies investigated the use of cognitive tools on participants at different levels of schooling consisting of preschool (6), elementary (22), secondary (18), undergraduate (39), graduate (2), in-service teachers or instructors (10), adult language learners (5), and others (6). These studies most often used academic content from science, mathematics, and language learning. Many of them, however, were laboratory studies of motivation, problem-solving, and learning strategies that used content not necessarily drawn from academic programs. Most of the studies investigating the use of cognitive tools by university students gathered data from courses in which they enrolled. In the 61 empirical studies examining the effectiveness of using cognitive tools to enhance learning or motivation, $42(68.9 \%)$ claimed the tools were effective, $12(19.7 \%)$ found no significant effect, and $7(11.5 \%)$ observed that other factors such as individual difference could moderate the effects of using the tools.

\section{Knowledge representation, interactivity, and distributed cognition}

Over time, the conceptualisation of cognitive tools has taken on multiple new meanings and shifted markedly from its roots in Soviet psychology. Vygotsky (1978) conceived of cognitive tools as constituents of culture that mediate instructional interactions and are internalised to become integral to learners' psychology and behaviour. Later, educational technology theorists such as Jonassen invoked different and sometimes conflicting conceptualisations to identify several types of software programs as cognitive tools and described how using them reorganises the cognitive structures of learners. Our systematic review showed how the term has gained significant currency in peer-reviewed research - most prominently in the field of educational technology but also educational psychology and other areas of educational research.

We found authors often claimed that the learning technologies they wrote about were cognitive tools without defining the term and without describing which features qualify the technology as a cognitive tool. Given the varying meanings and interpretations encountered in this review, we recommend that authors explain how they interpret the term cognitive tool, and - if they are referring to a particular diagram, idea, interface, or software application - explain why their purported instance should be considered a cognitive tool. The lack of definitional consensus also implies that, rather than review research on the broad concept of cognitive tools, meta-analyses should focus on specific features or categories of cognitive tools such as learner control in hypermedia environments (Scheiter \& Gerjets, 2007) or the instructional effectiveness of visualisation tools (McElhaney, Chang, Chiu, \& Linn, 2015).

Although we found disagreement about the definition of cognitive tools, we believe a core conceptualisation consisting of three attributes has emerged from Vygotsky (1978), Pea (1985), Salomon (1993), Jonassen (1992), Lajoie (1992), and several other theorists reviewed in the initial section of this article. Two of the attributes are alluded to by Preiss and Sternberg (2006, p. 15) when they explain that technologies designed as cognitive tools:

predominantly afford transformations on the symbolic aspects of cultural life and, eventually, transformations of the users of those technologies. In so doing, cognitive tools, as systems of representation, play a central role in both cultural evolution and cognitive development.

First, a cognitive tool is a system of concepts, and sometimes operations, represented to a learner in a form or technology that supports goal-oriented cognitive processing. The idea of a cognitive tool as knowledge representation runs through the work of almost all the theorists we have discussed. As a current example, the Dialectical Map (DM) is a type of interactive visualisation software that individual undergraduate students at Simon Fraser University use to construct arguments (Nesbit, Niu, \& Liu, 2019; Niu, 2016). Featuring a structure similar to an argumentation Vee diagram (Nussbaum, 2008), it provides text boxes for claims, reasons, warrants, and evidence that learners fill in and manipulate to show the pro and con sides of an argument. As a cognitive tool, it represents the culturally evolved constituents of argumentation and the relationships among them.

Second, as a result of extended interactivity with a cognitive tool, students internalise its related concepts and operations and may eventually be able to perform tasks that require those components without an external representation or device. As students use the DM to construct arguments over multiple occasions, 
they gradually reorganise their argumentation schema and eventually no longer need the software to construct arguments with warrants, rebuttals, and other advanced features. The idea that using knowledge representation tools reorganises or shapes learners' cognition was discussed by Pea (1985) and later others (Jonassen, 2000; Salomon et al., 1991).

The third attribute of a cognitive tool lies in its capacity for sustaining distributed cognition (Dror \& Harnad, 2008). While they are searching for and generating ideas to enter into the DM, students refer to it to keep track of which parts of a good argument have been assembled and which remain to be done. Their memory for key aspects of the task is partially outsourced to the tool. Many software tools perform computational operations more efficiently than is possible by a human, thereby enabling distributed cognitive processing (Jonassen et al., 1998). There is often no intention to internalise the operations performed by this type of tool, but instead to continue relying on the device indefinitely. We can identify such devices as cognitive tools and tools with which we work (Salomon et al., 1991) if in using them students learn how to invoke specific outsourced operations and the conditions under which to do so. University students who learn applied statistics by working with specialised statistical packages (e.g., SPSS) or languages such as or R usually continue to rely on the tools in more advanced courses or in any subsequent work as researchers. Nevertheless, working with such tools teaches them a great deal about the situations in which each statistical function should be used and the inputs and output for each function.

What implications does our definition have within the field of educational technology and learning design? Theorists have debated whether ITSs can be regarded as cognitive tools, with some arguing for (Koedinger \& Anderson, 1993; Pea, 1985) and others against (Jonassen, 1995; B. Kim \& Reeves, 2007). The interface for one version of the Algebra Cognitive Tutor ITS (Brunstein, Betts, \& Anderson, 2009, p. 792) provides a "transformation" menu from which students can choose one of four algebraic operations (e.g., "add to both sides"). At first, the ITS performs the selected operation, and at a later stage the student is expected to perform the operation. The list of available algebraic transformation operations provided by the menu qualifies as a simple cognitive tool because it represents task-relevant knowledge that can be internalised through repeated use of the tool. Also, the operations performed by the transformation menu afford distribution of cognitive operations to an external tool. The interface of the Algebra Cognitive Tutor has other features (e.g., the simplification menu) that can be regarded as cognitive tools for similar reasons. From our definition, then, the student interface of an ITS, or a component of the interface, can potentially be a cognitive tool.

What about more open learning environments like those discussed by Jonassen (1995) within which learners are able to imagine and then construct objects? Scratch is a programming environment designed to foster computational thinking (Resnick et al., 2009). Instead of keying in syntax-conforming code, students snap together virtual blocks shaped in ways that reflect their functionality. For example, the Repeat operation is represented by a C-shaped block into which the learner can snap the blocks to be iterated. Scratch has several key characteristics that qualify it as a cognitive tool. It represents key concepts and relationships of computational thinking, allows for cognitive processes to be distributed externally, and demands repeated meaningful interaction. Like the Algebra Cognitive Tutor that makes visible all available algebraic operations, the Scratch interface lowers the barrier to computational expression by displaying all the pluggable blocks from which programs can be constructed.

\section{Implications for design and research}

A complete account of principles for designing cognitive tools is outside the scope of this article, and here we merely demonstrate by example how three design principles flow, in part, from the conceptualisation of cognitive tools presented in the previous section. First, tools should be designed to represent knowledge in a way that is incompatible with common misconceptions and shows with special clarity concepts that students commonly find challenging or confusing. Second, the tool should be designed in such a way that novices can frequently interact with or refer to it as they complete tasks. Third, the tool should support students completing a challenging task by enabling them to offload or distribute to the tool memory or operations required by the task. These three principles - designing for representation, interactivity, and distributed cognition - imply that designers must develop clear learning goals and identify the barriers students encounter in attaining them. 


\section{Conclusion}

In this concluding section, we illustrate how the three principles are evident in the design of the DM (Nesbit et al., 2019; Niu, 2016) and nStudy (Winne, Nesbit, \& Popowich, 2017), another learning technology developed at Simon Fraser University. The DM was designed with attention to the key challenges that university students face in preparing well-reasoned arguments (Nesbit et al., 2019). They often ignore counterevidence, and they often fail to present and rebut counterarguments (Santos \& Santos, 1999). When they do acknowledge counterarguments, they may resist argument-counterargument integration such as introducing pertinent qualifications to the thesis (Nussbaum \& Schraw, 2007). Students also have difficulty judging the strength of evidence supporting claims and presenting the components of their argument in a coherent order. Inspired by its predecessor, the argumentation Vee diagram, the right half of the DM is dedicated to counterarguments and counterevidence. The three principles for designing cognitive tools are manifest in the design of the DM. The visual representation prompts students to construct balanced arguments that examine both sides of an issue. Students interact with the DM through several features designed around the key challenges we identified. They horizontally link related pro and con reasons and in so doing gain practice in argument-counterargument integration. The work of reorganising the order of the argument is partially distributed to the tool by a feature which allows students to move a claim (and any opposing claim linked to it) up or down to a new position. Each reason (pro or con) has a slider that students can adjust to represent the strength with which it supports or undermines the central thesis. When it is deployed in undergraduate biology classes, students who constructed arguments using the DM showed growth in the quality of their arguments over a series of three assignments (Niu, Sharp, \& Nesbit, 2015).

Studying educational resources places extraordinary demands on university students because they must simultaneously fulfill the dual tasks of cognitively processing information in multiple resources while strategically self-regulating that processing as they strive to achieve learning goals. nStudy is a collection of web-based cognitive tools designed to scaffold metacognitive monitoring and self-regulated learning for learners studying text, writing essays, or engaged in other forms of text-based information problem-solving (Winne et al., 2017). In the upcoming version of nStudy, instructors will be able to create specialised templates that represent schemas they intend learners to acquire. The templates can include text fields and sliders, akin to the palettes and belief meter of Bioworld, which prompt learners to record in the template what they know or believe about a topic they are investigating. The templates students fill in make their understanding of a topic more self-evident and invite the self-regulatory processes of evaluating and revising learning strategies. To fully acquire the schema represented by a template, a student may need to thoughtfully activate and complete a template artefact multiple times and in a variety of contexts.

nStudy is currently being augmented with learning analytics designed to motivate and guide students towards productive self-regulated learning (Winne, 2017; Winne \& Marzouk, 2019). Marzouk et al. (2016) described how learning analytics, beyond simply mirroring learners' behaviour, can visualise students' engagement with resources in ways that represent their learning strategies and foster their metacognition and motivation to learn. Goal setting is a crucial element of self-regulated learning. If students are able to set goals for studying by identifying materials they wish to study, the schedule they wish to follow, and the study tactics (e.g., tagging, note-taking) they wish to deploy, learning analytics can be configured to track and report to students their progress towards those goals. Seen as a cognitive tool for goal setting and goal fulfillment, the learning analytic described by Marzouk et al. exemplifies the three design principles of representation, interaction, and distributed cognition: Key concepts (resources, activities, schedule) and relationships among them are represented in the visualisation; the clerical task of gathering and aggregating trace data is distributed to the tool; and the students' repeated interactions with the tool are designed to help them internalise fundamental concepts and processes of self-regulated learning.

Because they can be operationally defined, the three attributes of representation, interactivity, and distributed cognition that characterise software-based cognitive tools also have a role to play in evaluating, iteratively redesigning, and researching the tools. Data gathered by means of log files, screen capture, eye tracking, and student products can be analysed to evaluate whether features of the tools are having their intended effects. To evaluate the interactivity of the DM interface, one could analyse screen captures and other trace data to determine whether, how often, and under which circumstances students are using the slider to estimate the strength of reasons. To evaluate distributed cognition, one could analyse eye-tracking data to investigate the extent to which students visually refer back to the DM as they search sources for evidence. To evaluate whether the representational structure of the DM has been internalised, one could 
look for its traces in the structure of essays students write later without the aid of the DM. Being derived from theory and amenable to operational definition, the three attributes we have described are suitable for guiding both hypotheses and methods in research on how cognitive tools can be designed to promote learning.

\section{Acknowledgements}

Support for this research was provided by a grant (435-2012-0723) from the Social Sciences and Humanities Research Council of Canada to John C. Nesbit.

\section{References}

Afamasaga-fuata'i, K. (2008). Students' conceptual understanding and critical thinking: A case for concept maps and vee-diagrams in mathematics problem solving. Australian Mathematics Teacher, 64(2), 8-18. Retrieved from https://search.informit.com.au/documentSummary; $\mathrm{dn}=243582554281479 ;$ res=IELHSS

Anderson, J. R., Corbett, A. T., Koedinger, K. R., \& Pelletier, R. (1995). Cognitive tutors: Lessons learned. The Journal of the Learning Sciences, 4(2), 167-207. https://doi.org/10.1037/a0016656

Arievitch, I. M., \& Stetsenko, A. (2000). The quality of cultural tools and cognitive development: Gal'perin's perspective and its implications. Human Development, 43, 69-92. https://doi.org/10.1159/000022661

Bender, A., \& Beller, S. (2012). Nature and culture of finger counting: Diversity and representational effects of an embodied cognitive tool. Cognition, 124(2), 156-182. https://doi.org/10.1016/j.cognition.2012.05.005

Brunstein, A., Betts, S., \& Anderson, J. R. (2009). Practice enables successful learning under minimal guidance. Journal of Educational Psychology, 101(4), 790-802.

Chen, S., Li, R., Li, G., Wang, Y., \& Wu, L. (2013). The effect of dialect experience on Chinese children's Mandarin phonological awareness. Reading and Writing, 26(8), 1317-1335. https://doi.org/10.1007/s11145-012-9420-5

Cole, M., \& Gajdamaschko, N. (2007). Vygotsky and culture. In H. Daniels, M. Cole, \& J. V. Wertsch (Eds.), The Cambridge companion to Vygotsky (pp. 193-211). New York, NY: Cambridge University Press. https://doi.org/10.1017/CCOL0521831040.009

Collins, G. W., \& Knoetze, J. G. (2014). Information communication technology in the form of an expert system shell as a cognitive tool to facilitate higher-order thinking. Australasian Journal of Educational Technology, 30(4), 455-471. https://doi.org/10.14742/ajet.189

Contreras, J. N. (2011). Using technology to unify geometric theorems about the power of a point. The Mathematics Educator, 21(1), 11-21. Retrieved from http://tme.journals.libs.uga.edu/index.php/tme/article/view/230/217

Dalgarno, B. (2001). Interpretations of constructivism and consequences for computer assisted learning. British Journal of Educational Technology, 32(2), 183-194. https://doi.org/10.1111/1467-8535.00189

Davydov, V. V., \& Tsvetkovich, Z. H. (1991). On the objective origin of the concept of fractions. Focus on Learning Problems in Mathematics, 13(1), 13-64. Retrieved from ERIC database. (EJ420530)

De la Colina, A. A., \& Mayo, M. G. (2009). Oral interaction in task-based EFL learning: The use of the L1 as a cognitive tool. International Review of Applied Linguistics in Language Teaching, 47(3-4), 325-345. https://doi.org/10.1515/iral.2009.014

Derry, S. J., \& Lajoie, S. P. (1993). A middle camp for (un)intelligent instructional computing: An introduction. In S. P. Lajoie \& S. J. Derry (Eds.), Computers as cognitive tools (pp. 1-11). Hillsdale, NJ: Erlbaum.

Dinsmore, D. L., Alexander, P. A., \& Loughlin, S. M. (2008). Focusing the conceptual lens on metacognition, self-regulation, and self-regulated learning. Educational Psychology Review, 20(4), 391-409. https://doi.org/10.1007/s10648-008-9083-6

DiSessa, A. A. (1983). Phenomenology and the evolution of intuition. In D. Gentner \& A. Stevens (Eds.), Mental models (pp. 15-33). Mahwah, NJ: Erlbaum.

Dror, I. E., \& Harnad, S. (Eds.). (2008). Cognition distributed: How cognitive technology extends our minds (Vol. 16). Amsterdam, PA: John Benjamins Publishing.

Duchastel, P. (1990). Assimilatory tools for informal learning: Prospects in ICAI. Instructional Science, 19(1), 3-9. https://doi.org/10.1007/BF00377982 
Edsall, R., \& Wentz, E. (2007). Comparing strategies for presenting concepts in introductory undergraduate geography: Physical models vs. computer visualization. Journal of Geography in Higher Education, 31(3), 427-444. https://doi.org/10.1080/03098260701513993

Gajdamaschko, N. (2015). Vygotsky’s sociocultural theory. In J. D. Wright (Ed.), International encyclopedia of social and behavioral sciences (2nd ed., pp. 329-334). Oxford, England: Elsevier.

Hung, W. (2008). Enhancing systems-thinking skills with modelling. British Journal of Educational Technology, 39(6), 1099-1120. https://doi.org/10.1111/j.1467-8535.2007.00791.x

Herrington, J. \& Parker, J. (2013). Emerging technologies as cognitive tools for authentic learning. British Journal of Educational Technology, 44(4), 607-615. https://doi.org/10.1111/bjet.12048

Iiyoshi, T., Hannafin, M. J., \& Wang, F. (2005). Cognitive tools and student-centred learning: Rethinking tools, functions and applications. Educational Media International, 42(4), 281-296. https://doi.org/10.1080/09523980500161346

Jonassen, D. H. (1992). What are cognitive tools? In P. Kommers, D. Jonassen, \& J. Mayes (Eds.), Cognitive tools for learning (pp. 1-6). Berlin, Germany: Springer-Verlag.

Jonassen, D. H. (1995). Computers as cognitive tools: Learning with technology, not from technology. Journal of Computing in Higher Education, 6(2), 40-73. https://doi.org/10.1007/BF02941038

Jonassen, D. H. (1996). Computers in the classroom: Mindtools for critical thinking. Columbus, $\mathrm{OH}$ : Prentice Hall.

Jonassen, D. H. (2000). Computers as mindtools for schools: Engaging critical thinking. Columbus, OH: Prentice Hall.

Jonassen, D. H. (2011). Supporting problem solving in PBL. Interdisciplinary Journal of Problem-Based Learning, 5(2), 95-112. https://doi.org/10.7771/1541-5015.1256

Jonassen, D. H., \& Carr, C. S. (2000). Mindtools: Affording multiple knowledge representations for learning. In S. P. Lajoie \& S. J. Derry (Eds.), Computers as cognitive tools: No more walls (Vol. 2, pp. 165-196). Mahwah, NJ: Erlbaum.

Jonassen, D. H., Carr, C., \& Yueh, H.-P. (1998). Computers as mindtools for engaging learners in critical thinking. TechTrends, 43(2), 24-32. https://doi.org/10.1007/BF02818172

Jonassen, D. H., \& Reeves, T. C. (1996). Learning with technology: Using computers as cognitive tools. In D. H. Jonassen (Ed.), Handbook of research for educational communications and technology (pp. 693-719). New York, NY: Simon \& Schuster Macmillan.

Kim, B., \& Reeves, T. C. (2007). Reframing research on learning with technology: in search of the meaning of cognitive tools. Instructional Science, 35(3), 207-256. https://doi.org/10.1007/s11251006-9005-2

Kim, M. C. (2012). Revisiting cognitive tools: Shifting the focus to tools-in-use. Educational Technology, 52(4), 14-24. Retrieved from http://www.jstor.org/stable/44430054

Koedinger, K. R., \& Anderson, J. R. (1993). Effective use of intelligent software in high school math classrooms. In P. Brna, S. Ohlsson, \& H. Pain (Eds.), Proceedings of the World Conference on Artificial Intelligence in Education (pp. 241-248). Charlottesville, VA: Association for the Advancment of Computing in Education.

Kozma, R. B. (1987). The implications of cognitive psychology for computer-based learning tools. Educational Technology, 27(11), 20-25. Retrieved from ERIC database. (EJ369287)

Lajoie, S. P. (1993). Computer environments as cognitive tools for enhancing learning. In S. P. Lajoie \& S. J. Derry (Eds.), Computers as cognitive tools (pp. 261-288). Hillsdale, NJ: Erlbaum.

Lajoie, S. P., Lavigne, N. C., Guerrera, C., \& Munsie, S. D. (2001). Constructing knowledge in the context of BioWorld. Instructional Science, 29(2), 155-186. https://doi.org/10.1023/A:1003996000775

Lenski, S. D., \& Nierstheimer, S. L. (2002). Strategy instruction from a sociocognitive perspective. Reading Psychology, 23(2), 127-143. https://doi.org/10.1080/027027102760351034

Li, R., \& Liu, M. (2007). Understanding the effects of databases as cognitive tools in a problem-based multimedia learning environment. Journal of Interactive Learning Research, 18(3), 345-363. Retrieved from https://learntechlib.org/p/21082/

Maclellan, E. (2008). Pedagogical literacy: What it means and what it allows. Teaching and Teacher Education, 24(8), 1986-1992. https://doi.org/10.1016/j.tate.2008.05.009

Martinovic, D., Burgess, G. H., Pomerleau, C. M., \& Marin, C. (2015). Comparison of children's gaming scores to NEPSY-II scores: Validation of computer games as cognitive tools. Computers in Human Behavior, 49, 487-498. https://doi.org/10.1016/j.chb.2015.03.039 
Marzouk, Z., Rakovic, M., Liaqat, A., Vytasek, J., Samadi, D., Stewart-Alonso, J., ... Nesbit, J. C. (2016). What if learning analytics were based on learning science? Australasian Journal of Educational Technology, 32(6), 1-18. https://doi.org/10.14742/ajet.30

McClary, L., \& Talanquer, V. (2011). College chemistry students' mental models of acids and acid strength. Journal of Research in Science Teaching, 48(4), 396-413. https://doi.org/10.1002/tea.20407

McElhaney, K. W., Chang, H.-Y., Chiu, J. L., \& Linn, M. C. (2015). Evidence for effective uses of dynamic visualisations in science curriculum materials. Studies in Science Education, 51(1), 49-85. https://doi.org/10.1080/03057267.2014.984506

Miller, K. F. (2000). Representational tools and conceptual change: The young scientist's tool kit. Journal of Applied Developmental Psychology, 21(1), 21-25. https://doi.org/10.1016/S01933973(99)00047-7

Mirolli, M., \& Parisi, D. (2009). Language as a cognitive tool. Minds and Machines, 19(4), 517-528. https://doi.org/10.1007/s11023-009-9174-2

Moshman, D. (1982). Exogenous, endogenous, and dialectical constructivism. Developmental Review, 2 , 371-384. https://doi.org/10.1016/0273-2297(82)90019-3

Nesbit, J. C., Niu, H., \& Liu, Q. (2019). Cognitive tools for scaffolding argumentation. In O. O. Adesope \& A.G. Rud (Eds.) Contemporary technologies in education: Maximizing student engagement, motivation, and learning (pp.97-117). London, England: Palgrave Macmillan.

Niu, H. (2016). Pedagogical efficacy of argument visualization tools (Doctoral dissertation). Retrieved from http://summit.sfu.ca/item/16608

Niu, H., Sharp, J., \& Nesbit, J. (2015, June). Teaching students argumentation with the dialectical map. Paper presented at the Annual Conference of the Society for Teaching and Learning in Higher Education, Vancouver, Canada.

Nussbaum, E. M. (2008). Using argumentation vee diagrams (AVDs) for promoting argumentcounterargument integration in reflective writing. Journal of Educational Psychology, 100(3), 549565. https://doi.org/10.1037/0022-0663.100.3.549

Nussbaum, E. M., \& Schraw, G. (2007). Promoting argument-counterargument integration in students' writing. Journal of Experimental Education, 76, 59-92. https://doi.org/10.3200/JEXE.76.1.59-92

Pea, R. D. (1985). Beyond amplification: Using the computer to reorganize mental functioning. Educational Psychologist, 20(4), 167-182. https://doi.org/10.1207/s15326985ep2004_2

Poitras, E., Lajoie, S., \& Hong, Y. J. (2012). The design of technology-rich learning environments as metacognitive tools in history education. Instructional science, 40(6), 1033-1061. https://doi.org/10.1007/s11251-011-9194-1

Preiss, D. D., \& Sternberg, R. J. (2006). Effects of technology on verbal and visual-spatial abilities. International Journal of Cognitive Technology, 11(1), 14-22. Retrieved from https://psycnet.apa.org/record/2006-09052-003

Puche-Navarro, R., \& Rodríguez-Burgos, L. P. (2015). Particularities and universalities of the emergence of inductive generalization. Integrative Psychological and Behavioral Science, 49(1), 104-124. https://doi.org/10.1007/s12124-014-9278-y

Resnick, M., Maloney, J., Monroy-Hernández, A., Rusk, N., Eastmond, E., Brennan, K., ... Kafai, Y. (2009). Scratch: Programming for all. Communications of the ACM, 52(11), 60-67. https://doi.org/10.1145/1592761.1592779

Salomon, G. (1993). On the nature of pedagogic computer tools: The case of the writing partner. In S. P. Lajoie \& S. J. Derry (Eds.), Computers as cognitive tools (pp. 179-196). Hillsdale, NJ: Erlbaum.

Salomon, G., Perkins, D. N., \& Globerson, T. (1991). Partners in cognition: Extending human intelligence with intelligent technologies. Educational Researcher, 20(3), 2-9.

https://doi.org/10.3102/0013189X020003002

Santos, C. M. M. \& Santos, S. L. (1999). Good argument, content and contextual dimensions. In J. Andriessen \& P. Coirier (Eds.), Foundations of argumentative text processing (pp. 75-95). Amsterdam, Netherlands: Amsterdam University Press.

Schack, T. (2004). The cognitive architecture of complex movement. International Journal of Sport and Exercise Psychology, 2(4), 403-438. https://doi.org/10.1080/1612197X.2004.9671753

Scheiter, K., \& Gerjets, P. (2007). Learner control in hypermedia environments. Educational Psychology Review, 19(3), 285-307. https://doi.org/10.1007/s10648-007-9046-3

Scher, D. (2000). Lifting the curtain: The evolution of the Geometer's Sketchpad. The Mathematics Educator, 10(1), 42-48. Retrieved from http://tme.journals.libs.uga.edu/index.php/tme/article/view/91 
Schmittau, J. (2003). Cultural-historical theory and mathematics education. In A. Kozulin, B. Gindis, V. Ageyev, \& S. Miller (Eds.), Vygotsky's educational theory in cultural context (pp. 225-245). Cambridge, MA: Cambridge University Press. https://doi.org/10.1017/CBO9780511840975.013

Stahl, G. (2006). Supporting group cognition in an online math community: A cognitive tool for smallgroup referencing in text chat. Journal of Educational Computing Research, 35(2), 103-122. https://doi.org/10.2190/Q435-7611-2561-720P

Tambouris, E., Zotou, M., \& Tarabanis, K. (2014). Towards designing cognitively-enriched projectoriented courses within a blended problem-based learning context. Education \& Information Technologies, 19(1), 61-86. https://doi.org/10.1007/s10639-012-9209-9

Taylor, R. (Ed.). (1980). The computer in the school: Tutor, tool, tutee. New York, NY: Teachers College press.

Von Glaserfeld, E. (1989). Cognition, construction of knowledge and teaching. Synthese, 80(1), 121-140. https://doi.org/10.1007/BF00869951

Vygotsky, L. S. (1930/1997). The instrumental method in psychology. In R. W. Rieber \& J. Wollock (Eds.) The collected works of L. S. Vygotsky: Problems of the theory and history of psychology (Vol. 3, pp. 85-89) New York, NY: Plenum.

Vygotsky, L. S. (1930/1999). Tools and sign in the development of the child. In R. W. Rieber (Ed.), The collected works of L. S. Vygotsky: Scientific legacy. (Vol. 6, pp. 3-68) New York, NY: Plenum

Vygotsky, L. S. (1962). Thought and language. Cambridge, MA: Harvard University Press.

Vygotsky, L. S. (1978). Mind in society: The development of higher psychological processes. Cambridge, MA: Harvard University Press.

Wertsch, J. (1998). Mind as action. Oxford, England: Oxford University Press.

Winne, P. H. (2017). Learning analytics for self-regulated learning. In C. Lang, G. Siemens, A. Wise, \& D. Gašević (Eds.), Handbook of learning analytics (pp. 241-249). Beaumont, Canada: Society for Learning Analytics Research.

Winne, P. H., \& Marzouk, Z. (2019). Learning strategies and self-regulated learning. In J. Dunlosky \& K. Rawson (Eds.), Cambridge handbook of cognition and education (pp. 696-715). New York, NY: Cambridge University Press.

Winne, P. H., Nesbit, J. C., \& Popowich, F. (2017). nStudy: A system for researching information problem solving. Technology, Knowledge and Learning, 22(3), 369-376. https://doi.org/10.1007/s10758-017-9327-y

Yildirim, Z. (2005). Hypermedia as a cognitive tool: Student teachers' experiences in learning by doing. Journal of Educational Technology \& Society, 8(2), 107-117. Retrieved from https://www.jets.net/ETS/journals/8_2/10.pdf

Zheng, J. (2015). Translation of metaphors in Business English from a cognitive perspective. International Journal of English Linguistics, 5(2), 132-138. https://doi.org/10.5539/ijel.v5n2p132

Corresponding author: Azar Pakdaman-Savoji, azar_pakdaman_savoji@sfu.ca

Please cite as: Pakdaman-Savoji, A., Nesbit, J. C., \& Gajdamaschko, N. (2019). The conceptualisation of cognitive tools in learning and technology: A review. Australasian Journal of Educational Technology, 35(2), 1-24. https://doi.org/10.14742/ajet.4704 


\section{Appendix: Supplementary references list for systematic review}

Adedoyin, A. O., \& Bello, G. (2017). Conceptions of the nature of science held by undergraduate preservice biology teachers in south-west Nigeria. Malaysian Online Journal of Educational Sciences, 5(1), 1-9.

Afamasaga-fuata'i, K. (2008). Students' conceptual understanding and critical thinking: A case for concept maps and vee-diagrams in mathematics problem solving. Australian Mathematics Teacher, 64(2), 8-18. Retrieved from https://search.informit.com.au/documentSummary; $\mathrm{dn}=243582554281479 ;$ res=IELHSS

Alagic, M., \& Palenz, D. (2006). Teachers explore linear and exponential growth: Spreadsheets as cognitive tools. Journal of Technology and Teacher Education, 14(3), 633-649.

Alfassi, M. (2009). The efficacy of a dialogic learning environment in fostering literacy. Reading Psychology, 30(6), 539-563. https://doi.org/10.1080/02702710902733626

Ali, J. (2009). Cognitive support through visualization and focus specification for understanding large class libraries. Journal of Visual Languages and Computing, 20(1), 50-59. https://doi.org/10.1016/j.jvlc.2008.02.001

Allegra, M., Chifari, A., \& Ottaviano, S. (2001). ICT to train students towards creative thinking. Educational Technology and Society, 4(2), 48-53.

Annan, J., Bowler, J., Mentis, M., \& Somerville, M. P. (2011). Between theory and practice falls the shadow: The learning theories profile. Journal of Cognitive Education and Psychology, 10(3), 238252. https://doi.org/10.1891/1945-8959.10.3.238

Anton, M., \& DiCamilla, F. J. (1999). Socio-cognitive functions of L1 collaborative interaction in the L2 classroom. Modern Language Journal, 83(2), 233-47

Arievitch, I. M., \& Stetsenko, A. (2000). The quality of cultural tools and cognitive development: Gal'perin's perspective and its implications. Human Development, 43, 69-92. https://doi.org/10.1159/000022661

Asoodar, M., Vaezi, S., \& Izanloo, B. (2016). Framework to improve e-learner satisfaction and further strengthen e-learning implementation. Computers in Human Behavior, 63, 704-716.

Astleitner, H. (2002). Teaching critical thinking online. Journal of Instructional Psychology, 29(2), 5376.

Azuma, H. (1982). Current trends in studies of behavioral development in Japan. International Journal of Behavioral Development, 5(2), 153-169.

Barrett, J. H. W. (1998). New knowledge and research in child development. Child and Family Social Work, 3, 267-276.

Bean, T. E., Sinatra, G. M., \& Schrader, P. G. (2010). Spore: Spawning evolutionary misconceptions? Journal of Science Education and Technology, 19(5), 409-414. https://doi.org/10.1007/s10956-010$\underline{9211-1}$

Beg, A., \& Ibrahim, W. (2009). PerfPred: A web-based tool for exploring computer architecture design space. Computer Applications in Engineering Education, 17(3), 305-313. https://doi.org/10.1002/cae.20243

Bender, A., \& Beller, S. (2012). Nature and culture of finger counting: Diversity and representational effects of an embodied cognitive tool. Cognition, 124(2), 156-182. https://doi.org/10.1016/j.cognition.2012.05.005

Benyon, D., \& Imaz, M. (1999). Metaphors and models: Conceptual foundations of representations in interactive systems development. Human-Computer Interaction, 14(1), 159-189.

Bera, S., \& Liu, M. (2006). Cognitive tools, individual differences, and group processing as mediating factors in a hypermedia environment. Computers in Human Behavior, 22(2), 295-319. https://doi.org/10.1016/j.chb.2004.05.001

Blake, C., \& Monahan, E. C. (2006). Wishful thinking or a bag of tricks? Helping the beginning special educator. Support for Learning, 21(1), 19-23. https://doi.org/10.1111/j.1467-9604.2006.00395.x

Bodrova, E., \& Leong, D. J. (2009). Tools of the mind: A Vygotskian based early childhood curriculum. Early Childhood Services, 3(3), 245-262.

Bonestroo, W. J., \& de Jong, T. (2012a). Effects of planning on task load, knowledge, and tool preference: A comparison of two tools. Interactive Learning Environments, 20(2), 141-153.

Bonestroo, W. J., \& de Jong, T. (2012b). The planning illusion: Does active planning of a learning route support learning as well as learners think it does? Educational Studies, 38(5), 559-571.

https://doi.org/10.1080/03055698.2012.659176 
Bromme, R., \& Stahl, E. (1999). Spatial metaphors and writing hypertexts: Studies with schools. European Journal of Psychology of Education, 14(2), 267-281.

Buckingham Shum, S., MacLean, A., Bellotti, V. M., \& Hammond, N. V. (1997). Graphical argumentation and design cognition. Human-Computer Interaction, 12(3), 267-300.

Bulle, N. (2014). Slow and fast thinking, historical-cultural psychology and major trends of modern epistemology: Unveiling a fundamental convergence. Mind and Society, 13(1), 149-166. https://doi.org/10.1007/s11299-014-0140-1

Caballé, S., Daradoumis, T., Xhafa, F., \& Juan, A. (2011). Providing effective feedback, monitoring and evaluation to on-line collaborative learning discussions. Computers in Human Behavior, 27(4), 13721381. https://doi.org/10.1016/j.chb.2010.07.032

Caglayan, G. (2014). Static versus dynamic disposition: The role of GeoGebra in representing polynomial-rational inequalities and exponential-logarithmic functions. Computers in the Schools, 31(4), 339-370. https://doi.org/10.1080/07380569.2014.967632

Campbell, T., Wang, S. K., Hsu, H. Y., Duffy, A. M., \& Wolf, P. G. (2010). Learning with web tools, simulations, and other technologies in science classrooms. Journal of Science Education and Technology, 19(5), 505-511. https://doi.org/10.1007/s10956-010-9217-8

Carrington, L., Kervin, L., \& Ferry, B. (2011). Enhancing the development of pre-service teacher professional identity via an online classroom simulation. Journal of Technology and Teacher Education, 19(3), 351-368.

Carswell, C. M., Bates, J. R., Pregliasco, N. R., Lonon, A., \& Urban, J. (1998). Finding graphs useful: Linking preference to performance for one cognitive tool. International Journal of Cognitive Technology, 3(1), 4-18.

Chambers, J. M., \& Carbonaro, M. (2003). Designing, developing, and implementing a course on LEGO robotics for technology teacher education. Journal of Technology and Teacher Education, 11(2), 209241.

Chen, S., Li, R., Li, G., Wang, Y., \& Wu, L. (2013). The effect of dialect experience on Chinese children's Mandarin phonological awareness. Reading and Writing, 26(8), 1317-1335. https://doi.org/10.1007/s11145-012-9420-5

Chen, Y. S., Kao, T. C., \& Sheu, J. P. (2005). Realizing outdoor independent learning with a butterflywatching mobile learning system. Journal of Educational Computing Research, 33(4), 395-417. https://doi.org/10.2190/0PAB-HRN9-PJ9K-DY0C

Cloutier, J., Mason, M. F., \& Macrae, C. N. (2005). The perceptual determinants of person construal: Reopening the social-cognitive toolbox. Journal of Personality and Social Psychology, 88(6), 885-94. https://doi.org/10.1037/0022-3514.88.6.885

Coffey, J. W. (2007). A meta-cognitive tool for courseware development, maintenance, and reuse. Computers and Education, 48(4), 548-566. https://doi.org/10.1016/j.compedu.2005.03.008

Collins, G. W., \& Knoetze, J. G. (2014). Information communication technology in the form of an expert system shell as a cognitive tool to facilitate higher-order thinking. Australasian Journal of Educational Technology, 30(4), 455-471. https://doi.org/10.14742/ajet.v30i4.189

Commendador, K., \& Chi, R. (2013). Comparative analysis of nursing students' perspectives toward avatar learning modality: gain pre-clinical experience via self-paced cognitive tool. Journal of Interactive Learning Research, 24(2), 151-166.

Contreras, J. N. (2011). Using technology to unify geometric theorems about the power of a point. The Mathematics Educator, 21(1), 11-21.

Crompton, H., Grant, M. R., \& Shraim, K. Y. H. (2018). Technologies to enhance and extend children's understanding of geometry: A configurative thematic synthesis of the literature. Educational Technology \& Society, 21(1), 59-69.

Collazo, N. A. J., Elen, J., \& Clarebout, G. (2015). The multiple effects of combined tools in computerbased learning environments. Computers in Human Behavior, 51, 82-95. https://doi.org/10.1016/j.chb.2015.04.050

Corcoran, K., Hundhammer, T., \& Mussweiler, T. (2009). A tool for thought! When comparative thinking reduces stereotyping effects. Journal of Experimental Social Psychology, 45(4), 1008-1011. https://doi.org/10.1016/j.jesp.2009.04.015

Cuevas, J. A., Russell, R. L., \& Irving, M. A. (2012). An examination of the effect of customized reading modules on diverse secondary students' reading comprehension and motivation. Educational Technology Research and Development, 60(3), 445-467. https://doi.org/10.1007/s11423-012-9244-7

Culligan, K. (2015). Student and teacher perceptions of first language use in secondary French immersion mathematics classrooms. Alberta Journal of Educational Research, 61(1), 1-19. 
Dalgarno, B. (2001). Interpretations of constructivism and consequences for computer assisted learning. British Journal of Educational Technology, 32(2), 183-194. https://doi.org/10.1111/1467-8535.00189

Danielson, J. A., Mills, E. M., Vermeer, P. J., Preast, V. A., Young, K. M., Christopher, M. M., ... Bender, H. S. (2007). Characteristics of a cognitive tool that helps students learn diagnostic problem solving. Educational Technology Research and Development, 55(5), 499-520. https://doi.org/10.1007/s11423-006-9003-8

Daugherty, J., \& Mentzer, N. (2008). Analogical reasoning in the engineering design process and technology education applications. Journal of Technology Education, 19(2), 7-21.

Davis, E. A, \& Krajcik, J. S. (2005). Designing educative curriculum materials to promote teacher learning. Educational Researcher, 34(3), 3-14. https://doi.org/10.3102/0013189X034003003

De la Colina, A. A., \& Mayo, M. G. (2009). Oral interaction in task-based EFL learning: The use of the L1 as a cognitive tool. International Review of Applied Linguistics in Language Teaching, 47(3-4), 325-345. https://doi.org/10.1515/iral.2009.014

Delgado, B., Gomez, J. C., \& Sarria, E. (2011). Pointing gestures as a cognitive tool in young children: Experimental evidence. Journal of Experimental Child Psychology, 110(3), 299-312. https://doi.org/10.1016/j.jecp.2011.04.010

Derry, S. J., Hmelo-Silver, C. E., Nagarajan, A., Chernobilsky, E., \& Beitzel, B. D. (2006). Cognitive transfer revisited: Can we exploit new media to solve old problems on a large scale? Journal of Educational Computing Research, 35(2), 145-162.

DeSchryver, M. D., Leahy, S. M., Koehler, M. J., \& Wolf, L. G. (2013). The habits of mind necessary to generate new ways of teaching in a career of constant change. TechTrends, 57(3), 40-46.

Dicks, D., \& Ives, C. (2007). Instructional designers at work: A Study of how designers design. Canadian Journal of Learning and Technology, 34(2), 91-108.

Dikli, S. (2006). Automated essay scoring. Turkish Online Journal of Distance Education, 7(1), 49-62.

Dowell, J., \& Long, J. (1998). Target paper: Conception of the cognitive engineering design problem. Ergonomics, 41(2), 126-139. https://doi.org/10.1080/001401398187125

Drie, J. V., Boxtel, C. V., Erkens, G., \& Kanselaar, G. (2005). Using representational tools to support historical reasoning in computer-supported collaborative learning. Technology, Pedagogy and Education, 14(1), 25-41.

Duchastel, P. (1990). Assimilatory tools for informal learning: Prospects in ICAI. Instructional Science, 19(1), 3-9. https://doi.org/10.1007/BF00377982

Duensing, S. (2000). Using Gal'perin's perspectives to explore generative learning in informal science centers. Human Development, 43(2), 107-114.

Duru, M., \& Martin-Clouaire, R. (2011). Cognitive tools to support learning about farming system management: a case study in grazing systems. Crop and Pasture Science, 62(9), 790. https://doi.org/10.1071/CP11121

Edsall, R., \& Wentz, E. (2007). Comparing strategies for presenting concepts in introductory undergraduate geography: Physical models vs. computer visualization. Journal of Geography in Higher Education, 31(3), 427-444. https://doi.org/10.1080/03098260701513993

Egan, K., Bullock, S., \& Chodakowski, A. (2016). Learning to teach, imaginatively: Supporting the development of new teachers through cognitive tools. McGill Journal of Education, 51(3), 999-1012.

Egan, K., \& Judson, G. (2009). Values and imagination in teaching: With a special focus on social studies. Educational Philosophy and Theory, 41(2), 126-140. https://doi.org/10.1111/j.14695812.2008.00455.x

Englert, C. S., Wu, X., \& Zhao, Y. (2005). Cognitive tools for writing: Scaffolding the performance of students through technology. Learning Disabilities Research \& Practice, 20(3), 184-198. https://doi.org/10.1111/j.1540-5826.2005.00132.x

Ertmer, P. A., \& Ottenbreit-Leftwich, A. (2013). Removing obstacles to the pedagogical changes required by Jonassen's vision of authentic technology-enabled learning. Computers and Education, 64, 175182. https://doi.org/10.1016/j.compedu.2012.10.008

Fettes, M., \& Judson, G. (2011). Imagination and the cognitive tools of place-making. The Journal of Environmental Education, 42(2), 123-135. https://doi.org/10.1080/00958964.2010.505967

Gajdamaschko, N. (2005). Theoretical concerns: Vygotsky on imagination development. Educational Perspectives, 39(2), 34-40.

Gao, P., Tan, S. C., Wang, L., Wong, A. F., \& Choy, D. (2011). Self reflection and preservice teachers' technological pedagogical knowledge: Promoting earlier adoption of student-centred pedagogies. Australasian Journal of Educational Technology, 27(6), 997-1013.

https://doi.org/10.14742/ajet.925 
Gebre, E. (2018). Learning with multiple representations: Infographics as cognitive tools for authentic learning in science literacy. Canadian Journal of Learning and Technology, 44(1).

Giardino, V. (2018a). Tools for thought: The case of mathematics. Endeavour, 42(2-3), 172-179.

Giardino, V. (2018 b). Manipulative imagination: How to move things around in mathematics. Theoria, 33(2), 345-360.

Gijlers, H., Saab, N., Van Joolingen, W. R., De Jong, T., \& Hout-Wolters, V. (2009). Interaction between tool and talk: How instruction and tools support consensus building in collaborative inquiry-learning environments. Journal of Computer Assisted Learning, 25(3), 252-267.

Gil-Arias, A., García-González, L., Del Villar, F., Moreno, A., \& Moreno, M. P. (2015). Effectiveness of video feedback and interactive questioning in improving tactical knowledge in volleyball. Perceptual and Motor Skills, 121(3), 635-653.

Gil-Arias, A., Moreno, M. P., García-Mas, A., Moreno, A., García-González, L., \& del Villar, F. (2016). Reasoning and action: Implementation of a decision-making program in sport. The Spanish Journal of Psychology, 19, e60, 1-9. https://doi.org/10.1017/sjp.2016.58

Girard, B., \& Harris, L. M. (2012). Striving for disciplinary literacy instruction: Cognitive tools in a world history course. Theory \& Research in Social Education, 40(3), 230-259. https://doi.org/10.1080/00933104.2012.705183

Gonzalez-Rosa, J. J., Natali, F., Tettamanti, A., Cursi, M., Velikova, S., Comi, G., ... \& Leocani, L. (2015). Action observation and motor imagery in performance of complex movements: evidence from EEG and kinematics analysis. Behavioural Brain Research, 281, 290-300. https://doi.org/10.1016/j.bbr.2014.12.016

Graci, C. (2009). A brief tour of the learning sciences via a cognitive tool for investigating melodic phenomena. Journal of Educational Technology Systems, 38(2), 181-211.

Hakkinen, P. (2003). Collaborative learning in networked environments: Interaction through shared workspaces and communication tools. Journal of Education for Teaching, 29(3), 279-281. https://doi.org/10.1080/0260747032000120178

Haenen, J. (2000). Gal'perian instruction in the ZPD. Human Development, 43(2), 93-98.

Hagler, D., White, B., \& Morris, B. (2011). Cognitive tools as a scaffold for faculty during curriculum redesign. Journal of Nursing Education, 50(7), 417-422. https://doi.org/10.3928/0148483420110214-03

Hansen, C.C. (2006). Technology as an electronic mentor: Scaffolding preservice teachers in writing effective literacy lesson plans. Journal of Early Childhood Teacher Education, 27(2), 129-148. https://doi.org/10.1080/10901020600675091

Herrington, J., \& Kervin, L. (2007). Authentic learning supported by technology: Ten suggestions and cases of integration in classrooms. Educational Media International, 44(3), 219-236. https://doi.org/10.1080/09523980701491666

Herrington, J., \& Parker, J. (2013). Emerging technologies as cognitive tools for authentic learning. British Journal of Educational Technology, 44(4), 607-615. https://doi.org/10.1111/bjet.12048

Hmelo-Silver, C. (2006). Introduction: Cognitive tools for collaborative communities. Journal of Educational Computing Research, 35(2), 97-102. https://doi.org/10.2190/8271-01Q8-68W5-4343

Hochpöchler, U., Schnotz, W., Rasch, T., Ullrich, M., Horz, H., McElvany, N., \& Baumert, J. (2013). Dynamics of mental model construction from text and graphics. European Journal of Psychology of Education, 28(4), 1105-1126. https://doi.org/10.1007/s10212-012-0156-Z

Hokanson, B., \& Hooper, S. (2000). Computers as cognitive media: Examining the potential of computers in education. Computers in Human Behavior, 16(5), 537-552. https://doi.org/10.1016/S07475632(00)00016-9

Honig, B. (2004). Entrepreneurship education: Toward a model of contingency-based business planning. Academy of Management Learning \& Education, 3(3), 258-273. https://doi.org/10.5465/AMLE.2004.14242112

Hooker, C. A. (2009). Interaction and bio-cognitive order. Synthese, 166(3), 513-546. https://doi.org/10.1007/s11229-008-9374-y

Hung, W. (2008). Enhancing systems-thinking skills with modelling. British Journal of Educational Technology, 39(6), 1099-1120. https://doi.org/10.1111/j.1467-8535.2007.00791.x

Iiyoshi, T., Hannafin, M. J., \& Wang, F. (2005). Cognitive tools and student-centred learning: Rethinking tools, functions and applications. Educational Media International, 42(4), 281-296.

Jakab, C. (2013). Small talk: Children's everyday "molecule" ideas. Research in Science Education, 43(4), 1307-1325. https://doi.org/10.1007/s11165-012-9305-2 
Jeong, H., \& Hmelo-Silver, C. E. (2010). Productive use of learning resources in an online problem-based learning environment. Computers in Human Behavior, 26(1), 84-99. https://doi.org/10.1016/j.chb.2009.08.001

Jonassen, D. H. (1995). Computers as cognitive tools: Learning with technology, not from technology. Journal of Computing in Higher Education, 6(2), 40-73. https://doi.org/10.1007/BF02941038

Jonassen, D. H. (2006). A constructivist's perspective on functional contextualism. Educational Technology Research and Development, 54(1), 43-47. https://doi.org/10.1007/s11423-006-6493-3

Jonassen, D. H., Campbell, J. P., \& Davidson, M. E. (1994). Learning with media: Restructuring the debate. Educational Technology Research and Development, 42(2), 31-39. https://doi.org/10.1007/bf02299089

Jones, A., \& Moreland, J. (2004). Enhancing practicing primary school teachers' pedagogical content knowledge in technology. International Journal of Technology and Design Education, 14(2), $121-$ 140. https://doi.org/10.1023/b:itde.0000026513.48316.39

Khan, T. M., \& Brown, K. (2000). Model-based training of situated skills. British Journal of Educational Technology, 31(2), 171-179.

Kim, B., \& Reeves, T. C. (2007). Reframing research on learning with technology: In search of the meaning of cognitive tools. Instructional Science, 35(3), 207-256. https://doi.org/10.1007/s11251006-9005-2

Kiramba, L. K. (2017). Translanguaging in the writing of emergent multilinguals. International Multilingual Research Journal, 11(2), 115-130.

Kirschner, P. A., \& Erkens, G. (2006). Cognitive tools and mindtools for collaborative learning. Journal of Educational Computing Research, 35(2), 199-209.

Kobayashi, Y. (1994). Conceptual acquisition and change through social interaction. Human Development, 37(4), 233-241.

Kong, S. C. (2008). The development of a cognitive tool for teaching and learning fractions in the mathematics classroom: A design-based study. Computers and Education, 51(2), 886-899. https://doi.org/1016/j.compedu.2007.09.007

Kong, S. C. (2011). An evaluation study of the use of a cognitive tool in a one-to-one classroom for promoting classroom-based dialogic interaction. Computers and Education, 57(3), 1851-1864. https://doi.org/10.1016/j.compedu.2011.04.008

Kong, S. C., \& Kwok, L. F. (2003). A graphical partitioning model for learning common fraction: Designing affordances on a web-supported learning environment. Computers and Education, 40(2), 137-155. https://doi.org/10.1016/S0360-1315(02)00118-5

Kong, S. C., \& Kwok, L. F. (2005). A cognitive tool for teaching the addition/subtraction of common fractions: A model of affordances. Computers and Education, 45(2), 245-265. https://doi.org/10.1016/j.compedu.2004.12.002

Kösem, S. D., \& Özdemir, Ö. F. (2014). The nature and role of thought experiments in solving conceptual physics problems. Science \& Education, 23(4), 865-895. https://doi.org/10.1007/s11191-013-9635-0

Lajoie, S. P. (2008). Metacognition, self regulation, and self-regulated learning: A rose by any other name? Educational Psychology Review, 20(4), 469-475. https://doi.org/10.1007/s10648-008-9088-1

Lappas, P. Z., \& Kritikos, M. N. (2018). Teaching and learning numerical analysis and optimization: A didactic framework and applications of inquiry-based learning. Higher Education Studies, 8(1), 42-57.

Latham, G., \& Ewing, R. (2018). Children's images of imagination: The language of drawings. Australian Journal of Language \& Literacy, 41(2), 71-81.

Leach, D. B. (2011). Children's recollections of a historic house visit: Recall of experiences and use of cognitive tools. Visitor Studies, 14(1), 34-47. https://doi.org/10.1080/10645578.2011.557627

Lebeau, R. B. (1998). Cognitive tools in a clinical encounter in medicine: Supporting empathy and expertise in distributed systems. Educational Psychology Review, 10(1), 3-24.

Lee, C. B. (2014). Technologies for literacy: using technologies in a problem solving environment. Australian Educational Computing, 29(2). Retrieved from http://journal.acce.edu.au/index.php/AEC/article/view/29

Lee, Y., \& Nelson, D. W. (2005). Design of a cognitive tool to enhance problem-solving performance. Educational Media International, 42(1), 3-18. https://doi.org/10.1080/09523980500116639

Lee, M. J., Pradhan, S., \& Dalgarno, B. (2008). The effectiveness of screencasts and cognitive tools as scaffolding for novice object-oriented programmers. Journal of Information Technology Education, 7, 61-80. Retrieved from https://www.learntechlib.org/p/111372/

Lenski, S. D., \& Nierstheimer, S. L. (2002). Strategy instruction from a sociocognitive perspective. Reading Psychology, 23(2), 127-143. https://doi.org/10.1080/027027102760351034 
Li, R., \& Liu, M. (2007). Understanding the effects of databases as cognitive tools in a problem-based multimedia learning environment. Journal of Interactive Learning Research, 18(3), 345-363.

Liu, M. (2004). Examining the performance and attitudes of sixth graders during their use of a problembased hypermedia learning environment. Computers in Human Behavior, 20(3), 357-379. https://doi.org/10.1016/S0747-5632(03)00052-9

Liu, M., \& Bera, S. (2005). An analysis of cognitive tool use patterns in a hypermedia learning environment. Educational Technology Research \& Development, 53(1), 5-21. https://doi.org/10.1007/BF02504854

Liu, M., Horton, L. R., Corliss, S. B., Svinicki, M. D., Bogard, T., Kim, J., \& Chang, M. (2009). Students' problem solving as mediated by their cognitive tool use: A study of tool use patterns. Journal of Educational Computing Research, 40(1), 111-139.

Liu, M., Williams, D., \& Pedersen, S. (2002). Alien Rescue: A problem-based hypermedia learning environment for middle school science. Journal of Educational Technology Systems, 30(3), 255-270. https://doi.org/10.2190/X531-D6KE-NXVY-N6RE

Liu, M., Yuen, T. T., Horton, L., Lee, J., Toprac, P., \& Bogard, T. (2013). Designing technology-enriched cognitive tools to support young learners' problem solving. The International Journal of Cognitive Technology, 18(1), 14-21.

Lorenzo, M. (2005). The development, implementation, and evaluation of a problem solving heuristic. International Journal of Science and Mathematics Education, 3(1), 33-58.

Lumpe, A. T., \& Butler, K. (2002). The information seeking strategies of high school science students. Research in Science Education, 32(4), 549-566.

Luo, P., Eikman, E. A., Kealy, W., \& Qian, W. (2006). Analysis of a mammography teaching program based on an affordance design model. Academic Radiology, 13(12), 1542-1552. https://doi.org/10.1016/j.acra.2006.08.016

Maclellan, E. (2008). Pedagogical literacy: What it means and what it allows. Teaching and Teacher Education, 24(8), 1986-1992. https://doi.org/10.1016/j.tate.2008.05.009

Manlove, S., Lazonder, A. W., \& de Jong, T. (2009). Collaborative versus individual use of regulative software scaffolds during scientific inquiry learning. Interactive Learning Environments, 17(2), 105117. https://doi.org/10.1080/10494820701706437

Marino, M. T. (2009). Understanding how adolescents with reading difficulties utilize technology-based tools. Exceptionality, 17(2), 88-102. https://doi.org/10.1080/09362830902805848

Markle, D. T. (2010). The magic that binds us: Magical thinking and inclusive fitness. Journal of Social, Evolutionary, and Cultural Psychology, 4(1), 18-33. https://doi.org/10.1037/h0099304

Martin-Beltrán, M. (2014). "What do you want to say?” How adolescents use translanguaging to expand learning opportunities. International Multilingual Research Journal, 8(3), 208-230. https://doi.org/10.1080/19313152.2014.914372

Martinovic, D., Burgess, G. H., Pomerleau, C. M., \& Marin, C. (2015). Comparison of children's gaming scores to NEPSY-II scores: Validation of computer games as cognitive tools. Computers in Human Behavior, 49, 487-498. https://doi.org/10.1016/j.chb.2015.03.039

Mattisson, J., \& Schamp-Bjerede, T. (2010). A new twist on an old tool: joint learning with an innovative cognitive writing tool. Journal of College Teaching and Learning, 7(8), 45-54.

McClary, L., \& Talanquer, V. (2011). College chemistry students' mental models of acids and acid strength. Journal of Research in Science Teaching, 48(4), 396-413. https://doi.org/10.1002/tea.20407

McNaughton, D., \& Bryen, D. N. (2007). AAC technologies to enhance participation and access to meaningful societal roles for adolescents and adults with developmental disabilities who require AAC. Augmentative and Alternative Communication, 23(3), 217-229. https://doi.org/10.1080/07434610701573856

Miller, K. F. (2000). Representational tools and conceptual change: The young scientist's tool kit. Journal of Applied Developmental Psychology, 21(1), 21-25. https://doi.org/10.1016/S01933973(99)00047-7

Mirolli, M., \& Parisi, D. (2009). Language as a cognitive tool. Minds and Machines, 19(4), 517-528. https://doi.org/10.1007/s11023-009-9174-2

Mirolli, M., \& Parisi, D. (2011). Towards a Vygotskyan cognitive robotics: The role of language as a cognitive tool. New Ideas in Psychology, 29(3), 298-311. https://doi.org/10.1016/j.newideapsych.2009.07.001

Moher, M., Feigenson, L., \& Halberda, J. (2010). A one-to-one bias and fast mapping support preschoolers' learning about faces and voices. Cognitive Science, 34(5), 719-751. https://doi.org/10.1111/j.1551-6709.2010.01109.x 
Morgan, M., Brickell, G., \& Harper, B. (2008). Applying distributed cognition theory to the redesign of the "Copy and Paste" function in order to promote appropriate learning outcomes. Computers and Education, 50(1), 125-147. https://doi.org/10.1016/j.compedu.2006.04.006

Morineau, T., Blanche, C., Tobin, L., \& Gueguen, N. (2005). The emergence of the contextual role of the e-book in cognitive processes through an ecological and functional analysis. International Journal of Human Computer Studies, 62(3), 329-348. https://doi.org/10.1016/j.ijhcs.2004.10.002

Nesbit, J. C., Winne, P. H., \& Jamieson-Noel, D. (2006). Using cognitive tools in gStudy to investigate how study activities covary with achievement goals. Journal of Educational Computing Research, 35(4), 339-358.

Nickerson, J. V., Corter, J. E., Tversky, B., Rho, Y. J., Zahner, D., \& Yu, L. (2013). Cognitive tools shape thought: diagrams in design. Cognitive Processing, 14(3), 255-272. https://doi.org/10.1007/s10339013-0547-3

Nietfeld, J. L., Shores, L. R., \& Hoffmann, K. F. (2014). Self-regulation and gender within a game-based learning environment. Journal of Educational Psychology, 106(4), 961-973.

https://doi.org/10.1037/a0037116

Nishioka, H. (2016). Analysing language development in a collaborative digital storytelling project: Sociocultural perspectives. System, 62, 39-52.

Norton, S. (2017). Mathematics engagement in an Australian lower secondary school. Journal of Curriculum Studies, 49(2), 169-190.

Nyland, B., Ferris, J., \& Dunn, L. (2008). Mindful hands, gestures as language: Listening to children. Early Years, 28(1), 73-80. https://doi.org/10.1080/09575140701846552

O’Neill, D. K., \& Weiler, M. J. (2006). Cognitive tools for understanding history: What more do we need? Journal of Educational Computing Research, 35(2), 181-197. https://doi.org/10.2190/H22P7718-81G5-0723

O’Sullivan, Í. (2007). Enhancing a process-oriented approach to literacy and language learning: The role of corpus consultation literacy. ReCALL, 19(3), 269-286.

https://doi.org/10.1017/S095834400700033X

Oubenaissa, L., Giardina, M., \& Bhattacharya, M. (2002). Designing a framework for the implementation of situated online, collaborative, problem-based activity: Operating within a local and multi-cultural learning context. International Journal on E-Learning, 1(3), 41-46.

Ozcelik, E., \& Yildirim, S. (2005). Factors influencing the use of cognitive tools in web-based learning environments: A case study. Quarterly Review of Distance Education, 6(4), 295-307.

Palaigeorgiou, G. E., Despotakis, T. D., Demetriadis, S., \& Tsoukalas, I. A. (2006). Synergies and barriers with electronic verbatim notes (eVerNotes): Note taking and report writing with eVerNotes. Journal of Computer Assisted Learning, 22(1), 74-85. https://doi.org/10.1111/j.13652729.2006.00161.x

Palincsar, A. S., \& Herrenkohl, L. R. (2002). Designing collaborative learning contexts. Theory Into Practice, 41(1), 26-32. https://doi.org/10.1207/s15430421tip4101_5

Pape, S. J., \& Tchoshanov, M. A. (2001). The role of representation (s) in developing mathematical understanding. Theory into Practice, 40(2), 118-127. https://doi.org/10.1207/s15430421tip4002 6

Peralta, O., Salsa, A., Maita, M. D. R., \& Mareovich, F. (2013). Scaffolding young children's understanding of symbolic objects. Early Years, 33(3), 266-274. https://doi.org/10.1080/09575146.2012.732042

Poitras, E., Lajoie, S., \& Hong, Y. J. (2012). The design of technology-rich learning environments as metacognitive tools in history education. Instructional Science, 40, 1033-1061. https://doi.org/10.1007/s11251-011-9194-1

Preiss, D. D., \& Sternberg, R. J. (2006). Effects of technology on verbal and visual-spatial abilities. International Journal of Cognitive Technology, 11(1), 14-22. Retrieved from https://psycnet.apa.org/record/2006-09052-003

Puche-Navarro, R., \& Rodríguez-Burgos, L. P. (2015). Particularities and universalities of the emergence of inductive generalization. Integrative Psychological and Behavioral Science, 49(1), 104-124. https://doi.org/10.1007/s12124-014-9278-y

Ravenscroft, A., \& Matheson, M. P. (2002). Developing and evaluating dialogue games for collaborative e-learning. Journal of Computer Assisted Learning, 18, 93-101. https://doi.org/10.1046/j.02664909.2001.00215.x

Reboul, A. (2012). Language: Between cognition, communication and culture. Pragmatics \& Cognition, 20(2), 295-316. https://doi.org/10.1075/pc.20.2.06reb 
Reynolds, T. H., \& Bonk, C. J. (1996). Computerized prompting partners and keystroke recording devices: Two macro driven writing tools. Educational Technology Research and Development, 44(3), 83-97.

Roebuck, R. F., \& Wagner, L. C. (2004). Teaching repetition as a communicative and cognitive tool: evidence from a Spanish conversation class. International Journal of Applied Linguistics, 14(1), 7089. https://doi.org/10.1111/j.1473-4192.2004.00054.X

Ruthven, K., \& Chaplin, D. (1997). The calculator as a cognitive tool: Upper-primary pupils tackling a realistic number problem. International Journal of Computers for Mathematical Learning, 2(2), 93 124.

Saban, A., Kocbeker, B. N., \& Saban, A. (2007). Prospective teachers' conceptions of teaching and learning revealed through metaphor analysis. Learning and Instruction, 17(2), 123-139. https://doi.org/10.1016/j.learninstruc.2007.01.003

Sackur-Grisvard, C., \& Léonard, F. (1985). Intermediate cognitive organizations in the process of learning a mathematical concept: The order of positive decimal numbers. Cognition and Instruction, 2(2), 157-174. https://doi.org/10.1207/s1532690xci0202_ 3

Schack, T. (2004). The cognitive architecture of complex movement. International Journal of Sport and Exercise Psychology, 2(4), 403-438. https://doi.org/10.1080/1612197X.2004.9671753

Schack, T., \& Ritter, H. (2013). Representation and learning in motor action - Bridges between experimental research and cognitive robotics. New Ideas in Psychology, 31(3), 258-269. https://doi.org/10.1016/j.newideapsych.2013.04.003

Schnotz, W., \& Preuß, A. (1997). Task-dependent construction of mental models as a basis for conceptual change. European Journal of Psychology of Education, 12(2), 185-211 https://doi.org/10.1007/BF03173084

Schnotz, W., \& Wagner, I. (2018). Construction and elaboration of mental models through strategic conjoint processing of text and pictures. Journal of Educational Psychology, 110(6), 850-863.

Schoultz, J., Säljö, R., \& Wyndhamn, J. (2001). Heavenly talk: Discourse, artifacts, and children's understanding of elementary astronomy. Human Development, 44(2-3), 103-118. https://doi.org/10.1159/000057050

Sedig, K., \& Liang, H. N. (2006). Interactivity of visual mathematical representations: Factors affecting learning and cognitive processes. Journal of Interactive Learning Research, 17(2), 179-212.

Sedig, K., \& Liang, H. N. (2008). Learner-information interaction: A macro-level framework characterizing visual cognitive tools. Journal of Interactive Learning Research, 19(1), 147-173.

Sedig, K., \& Sumner, M. (2006). Characterizing interaction with visual mathematical representations. International Journal of Computers for Mathematical Learning, 11(1), 1-55. https://doi.org/10.1007/s10758-006-0001-z

Smith, J. G., \& Smith, R. L. (2012). Screen-capture instructional technology: A cognitive tool for designing a blended multimedia curriculum. Journal of Educational Computing Research, 46(3), 207228. https://doi.org/10.2190/EC.46.3.a

Stahl, G. (2006). Supporting group cognition in an online math community: A cognitive tool for smallgroup referencing in text chat. Journal of Educational Computing Research, 35(2), 103-122. https://doi.org/10.2190/Q435-7611-2561-720P

Tambouris, E., Zotou, M., \& Tarabanis, K. (2014). Towards designing cognitively-enriched projectoriented courses within a blended problem-based learning context. Education \& Information Technologies, 19(1), 61-86.

Teräs, H., \& Kartoglu, Ü. (2018). Authentic learning with technology for professional development in vaccine management. Australasian Journal of Educational Technology, 34(3), 15-29.

Tsai, C. C. (2004). Beyond cognitive and metacognitive tools: The use of the Internet as an 'epistemological' tool for instruction. British Journal of Educational Technology, 35(5), 525-536. https://doi.org/10.1111/j.0007-1013.2004.00411.x

Tsai, P. S., \& Tsai, C. C. (2013). College students' experience of online argumentation: Conceptions, approaches and the conditions of using question prompts. Internet and Higher Education, 17, 38-47. https://doi.org/10.1016/j.iheduc.2012.10.001

Tupper, K. W. (2002). Entheogens and existential intelligence: The use of plant teachers as cognitive tools. Canadian Journal of Education, 27(4), 499-516. https://doi.org/10.2307/1602247

Tzuriel, D., Kaniel, S., Kanner, E., \& Haywood, H. C. (1999). Effects of the "bright start" program in kindergarten on transfer and academic achievement. Early Childhood Research Quarterly, 14(1), 111-141. https://doi.org/10.1016/S0885-2006(99)80009-X 
Vanoh, D., Ishak, I. H., Shahar, S., Manaf, Z. A., Ali, N. M., \& Noah, S. A. M. (2018). Development and assessment of a web-based intervention for educating older people on strategies promoting healthy cognition. Clinical Interventions in Aging, 13, 1787-1798.

Veraksa, A. N. (2011). Symbolic mediation in cognitive activity. International Journal of Early Years Education, 19(1), 89-102.

Veraksa, A. N. (2013). Symbol as a cognitive tool. Psychology in Russia: State of the Art, 6(1), 57-65. https://doi.org/10.11621/pir.2013.0105

Vidal, C. (2010). Computational and biological analogies for understanding fine-tuned parameters in physics. Foundations of Science, 15(4), 375-393. https://doi.org/10.1007/s10699-010-9183-x

Virgo, J., Pillon, J., Navarro, J., Reynaud, E., \& Osiurak, F. (2017). Are you sure you're faster when using a cognitive tool? The American Journal of Psychology, 130(4), 493-503.

Vohle, F. (2009). Cognitive tools 2.0 in trainer education. International Journal of Sports Science \& Coaching, 4(4), 583-595.

Wan, W., Low, G. D., \& Li, M. (2011). From students' and teachers' perspectives: Metaphor analysis of beliefs about EFL teachers' roles. System, 39, 403-415. https://doi.org/10.1016/j.system.2011.07.012

Wang, S.-K., \& Hsu, H.-Y. (2017). A design-based research capturing science teachers' practices of information and communication technologies (ICTs) integration using the new literacy framework. Journal of Computers in Mathematics and Science Teaching, 36(4), 387-396.

Wang, S.-K., Hsu, H.-Y., Reeves, T. C., \& Coster, D. C. (2014). Professional development to enhance teachers' practices in using information and communication technologies (ICTs) as cognitive tools: Lessons learned from a design-based research study. Computers \& Education, 79, 101-115.

Wang, M., Wu, B., Chen, N. S., \& Spector, J. M. (2013). Connecting problem-solving and knowledgeconstruction processes in a visualization-based learning environment. Computers \& Education, 68 , 293-306. https://doi.org/10.1016/i.compedu.2013.05.004

Wilson, M. (2010). The re-tooled mind: How culture re-engineers cognition. Social Cognitive and Affective Neuroscience, 5(2-3), 180-187. https://doi.org/10.1093/scan/nsp054

Wong, W. K., Chan, T. W., Chou, C. Y., Heh, J. S., \& Tung, S. H. (2003). Reciprocal tutoring using cognitive tools. Journal of Computer Assisted Learning, 19(4), 416-428. https://doi.org/10.1046/j.0266-4909.2003.00046.x

$\mathrm{Wu}, \mathrm{S}$. Y., \& Hou, H. T. (2014). Exploring the process of planning and implementation phases in an online project-based discussion activity integrating a collaborative concept-mapping tool. The AsiaPacific Education Researcher, 23(1), 135-141. https://doi.org/10.1007/s40299-013-0089-6

Yamamoto, Y., \& Nakakoji, K. (2005). Interaction design of tools for fostering creativity in the early stages of information design. International Journal of Human Computer Studies, 63, 513-535. https://doi.org/10.1016/j.ijhcs.2005.04.023

Yerkey, N. (1993). TOPOS: An advice system for the invention of persuasive arguments. Journal of Educational Computing Research, 9(4), 519-534.

Yildirim, Z. (2005). Hypermedia as a cognitive tool: Student teachers' experiences in learning by doing. Journal of Educational Technology \& Society, 8(2). 107-117.

Zheng, J. (2015). Translation of metaphors in business English from a cognitive perspective. International Journal of English Linguistics, 5(2), 132-138. https://doi.org/10.5539/ijel.v5n2p132

Zheng, R. Z., Flygare, J. a., \& Dahl, L. B. (2009). Style matching or ability building? An empirical study on FD learners' learning in well-structured and ill-structured asynchronous online learning environments. Journal of Educational Computing Research, 41(2), 195-226. https://doi.org/10.2190/EC.41.2.d

Zydney, J. M. (2008). Cognitive tools for scaffolding students defining an ill-structured problem. Journal of Educational Computing Research, 38(4), 353-385. https://doi.org/10.2190/EC.38.4.a 